\title{
AN ANALYSIS OF SPECIES DISTRIBUTION PATTERNS IN THE ATLANTIC FORESTS OF SOUTHEASTERN BRAZIL
}

\author{
M. F. SAntor ${ }^{1,2}, \mathrm{H} \cdot \mathrm{Serafim}^{1} \& \mathrm{P} \cdot \mathrm{T} \cdot \mathrm{SANO}^{1}$
}

This study analysed phytogeographic patterns of several Atlantic Forest areas in southeastern Brazil, including forest areas in the Espinhaço Range, to identify species with congruent distribution patterns and possible environmental factors that might influence these. A total of 54 floristic surveys, predominantly from semideciduous woodland sites but also including some rainforest areas, were compared using UPGMA and DCA methods as well as Jaccard analyses. The former identified four main groupings: group 1 included forests located throughout the Espinhaço Range; group 2 was formed by forest areas in the Rio Jequitinhonha basin; group 3 was formed by three distinct subgroups, one (3.1) predominantly of forest areas pertaining to the Alto Rio Grande basin, another (3.2) of upland forests of the Quadrilátero Ferrífero, and a third subgroup (3.3) of upland forests of the Serra da Mantiqueira; and group 4 encompassed forest areas in the Rio Doce, Rio Paraíba do Sul, Rio Itanhém and Rio Itapemirim basins. The prevailing relief in these basins has influenced rainfall and seasonality in these areas which, in turn, have exerted a major influence on the composition of the semideciduous forests. Geographic proximity and altitude, although important factors, play a minor role in the phytogeographic patterns analysed. Despite the floristic heterogeneity of the Espinhaço Range forests, there are physiognomic and floristic affinities among the forests within the campos rupestre vegetation. These are due to the high altitude and features of the soil.

Keywords. Atlantic Semideciduous Forests, Espinhaço Range, geographic distribution, phytogeography, Quadrilátero Ferrífero.

\section{INTRODUCTION}

Many studies on the phytogeography of the Brazilian Atlantic Forest have focused on physiognomic and climatic features (Campos, 1926; Santos, 1943; Rizzini, 1979; Veloso et al., 1991), and it is only more recently, with advances in taxonomic knowledge, that floristic correlations have also been included (Oliveira-Filho et al., 1994, 2006; Torres et al., 1997; Ivanauskas et al., 2000; Oliveira-Filho \& Fontes, 2000; Santos et al., 2007; Kamino et al., 2008).

Oliveira-Filho \& Fontes (2000) analysed the floristic composition of 125 forest areas in southeastern Brazil and correlated them to environmental factors. They

\footnotetext{
${ }^{1}$ Universidade de São Paulo, Departamento de Botânica, Laboratório de Sistemática Vegetal, Rua do Matão 277, 05508-090, São Paulo, SP, Brazil. E-mail for correspondence: matheus_fs@yahoo.com.br

2 Part of the first author's masters dissertation at the Universidade de São Paulo.
} 
demonstrated a marked floristic affinity between the rain forest and semideciduous and mixed forests, which many authors (Campos, 1926; Santos, 1943; Rizzini, 1979; Leitão-Filho, 1987; Veloso et al., 1991) had considered as distinct formations, influenced by physiognomic and climatic features. Based on the marked floristic similarities, Oliveira-Filho \& Fontes (2000) proposed the recognition of the Atlantic Forest domain, encompassing all the forest physiognomies of eastern Brazil. Also, in a study of the phytogeographic patterns of eastern Brazilian river basins, OliveiraFilho et al. (2005) concluded that floristic differences between rain and semideciduous forests are dictated mainly by the length of the dry season and the average annual rainfall, although both factors show a continuous latitudinal variation.

A number of studies (Salis et al., 1995; Torres et al., 1997; Ivanauskas et al., 2000) have emphasised the influence of annual rainfall pattern, as well as altitude, on floristic similarity between areas of the Atlantic Forest in São Paulo State. Scudeller et al. (2001) commented on the pronounced floristic disparities between rainforest areas of such Atlantic Forest. Other studies on the floristic relationships between semideciduous forest areas in the Alto Rio Grande basin (Minas Gerais State) have shown that geographic proximity and altitude exert an influence on similarity patterns, together with other variables such as available water and soil characteristics (OliveiraFilho et al., 1994; Van den Berg \& Oliveira-Filho, 2000; Gonzaga et al., 2008).

Studies by Kamino et al. (2008) on 18 forest areas extending along the Espinhaço Range, one of the western limits of the Atlantic Forest, demonstrated four arboreal floristic groups that correlated with geographic and climatic variables: the 'Quadrilátero Ferrífero', comprising those sites found in the Quadrilátero Ferrifero; the 'Chapada de São Domingos', for the sites in the eastern Septentrional Espinhaço; the 'Espinhaço Central', for the sites in the central part of the Espinhaço Range; and the 'Septentrional Disjunctions of the Chapada Diamantina', comprising the sites in the northern Chapada Diamantina (see geomorphological description of the Espinhaço Range below).

In the present study we used floristic surveys to evaluate phytogeographic patterns in the Atlantic Semideciduous Forests in southeastern Brazil, particularly in the areas of the eastern river basins (sensu Oliveira-Filho et al., 2005), the Alto Rio Grande basin, and the Espinhaço Range. We aimed to (i) analyse the phytogeographic patterns in these areas as related to the Atlantic Forest domain, (ii) analyse in detail the phytogeographic patterns of forest areas in the Espinhaço Range, (iii) identify species that show congruent distributions with the phytogeographic patterns, and (iv) look for possible environmental factors that exert an influence on the patterns observed.

\section{Study Areas and Methodology}

\section{Atlantic Forest}

The Atlantic Forest sensu lato includes rain forest (Atlantic Forest sensu stricto) as well as mixed, semideciduous and deciduous forests (Joly et al., 1999; OliveiraFilho \& Fontes, 2000). It originally extended over some $3300 \mathrm{~km}$ of the eastern part 
of South America, between latitudes $6^{\circ}$ and $30^{\circ} \mathrm{S}$, and up to $700 \mathrm{~km}$ inland, covering a total area of 1.1 million $\mathrm{km}^{2}$ (Fernandes \& Bezerra, 1990; SOS Mata Atlântica \& INPE, 1993; Oliveira-Filho \& Fontes, 2000).

In the Atlantic Forest, the rain forests occur in areas where the dry season lasts for 30 days or less. This comprises mainly the coastal areas up to $50-300 \mathrm{~km}$ inland. The semideciduous forests occur where the dry season lasts for 40-160 days, occupying areas up to $700 \mathrm{~km}$ inland. The transitions between these two contiguous forest types are very complex and may be gradual or abrupt (Oliveira-Filho \& Fontes, 2000).

\section{Espinhaço Range}

The Espinhaço Range extends for c. $1200 \mathrm{~km}$ north-south from the central region of Minas Gerais to the northern limit of Bahia (Almeida-Abreu \& Renger, 2002) (Fig. 1A). It is divided into Septentrional and Meridional zones, and the region called 'Chapada Diamantina'. Each of these regions differs in geological and geomorphological aspects (Pedreira, 1994; Almeida-Abreu, 1995; Saadi, 1995; Almeida-Abreu \& Renger, 2002). Overall the present geomorphological constitution of the Espinhaço Range is best termed a plateau (Saadi, 1995), and is the result of tectonic, glacial and erosive processes since the Mesoproterozoic Age (Saadi, 1995; Almeida-Abreu \& Renger, 2002). The main geological formation of the Espinhaço Range is the Espinhaço Supergroup, formed mostly by quartzitic lithologies (Almeida-Abreu, 1995; Saadi, 1995). In the shallow and oligotrophic quartzite soils the typical xeromorphic vegetation of the Espinhaço, called the campo rupestre, occurs. This vegetation is dominated by certain families, such as Eriocaulaceae, Velloziaceae and Xyridaceae (Giulietti et al., 1987, 1997). However, in places where other lithologies predominate, a deep mesotrophic soil can be formed, thus permitting the establishment of extensive, tall forests (Almeida-Abreu et al., 2005).

The Quadrilátero Ferrifero is an iron-ore rich area contiguous with the south of the Espinhaço Range, comprising a roughly quadrangular arrangement of synclines with outcropping sedimentary platforms of the Minas Supergroup (Palaeoproterozoic Age), that are separated by Archean and Proterozoic geological formations (Rosière \& Chemale Jr., 2000). Gontijo (2008) included the 'Quadrilátero Ferrífero' formation as part of a more ample definition of the term Espinhaço Range. Here we consider the Espinhaço Range and the 'Quadrilátero Ferrífero' as distinct formations, due to the differences in their age and lithology (see Almeida-Abreu, 1995; Saadi, 1995; Rosière \& Chemale Jr., 2000; Almeida-Abreu \& Renger, 2002). The Quadrilátero Ferrifero was included in this study due to its proximity to the Espinhaço, with the two formations constituting a continuous assemblage of elevations (Fig. 1A).

\section{Data analysis}

Data from 54 published arboreal floristic surveys in the Atlantic Forest sensu lato in southeastern Brazil and in the Espinhaço Range were selected for analysis (Fig. 1B; 


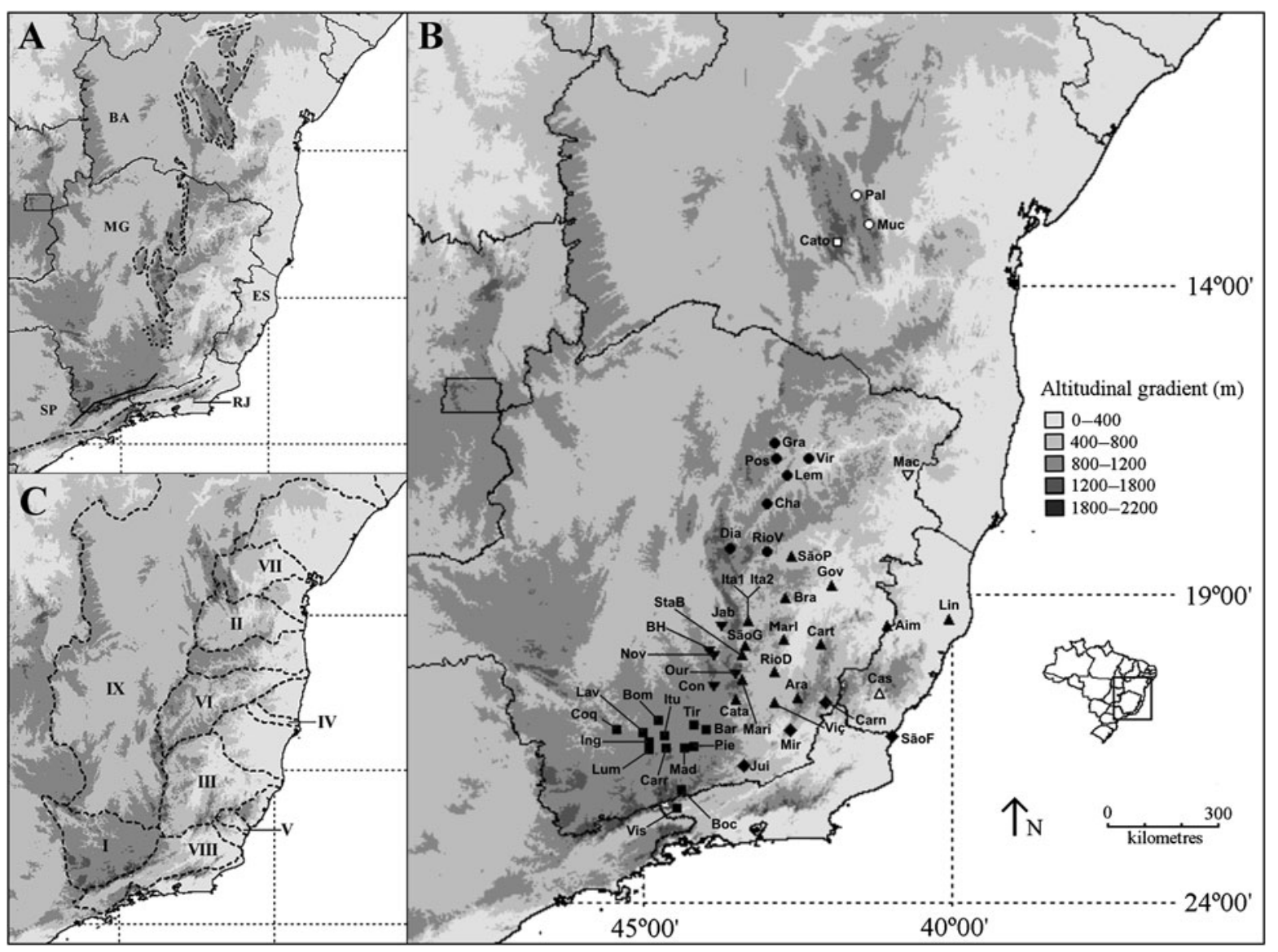

FIG. 1. (A) Geomorphological areas and Brazilian states cited in the text. Legend: Solid line delineates states $(\mathrm{BA}=\mathrm{Bahia}, \mathrm{ES}=\mathrm{Espírito}$ Santo, $\mathrm{MG}=$ Minas Gerais, RJ = Rio de Janeiro, SP = São Paulo). Dashed line delineates the Espinhaço Supergroup. Dotted line delineates the Quadrilátero Ferrífero. Dashed line \pm parallel to coast $=$ extension of the Serra do Mar. Solid line \pm parallel to coast $=$ extension of the Serra da 
Table 1). These included five surveys in Atlantic Rain Forests and 49 in areas of Atlantic Semideciduous Forests, of which 10 were in the Espinhaço Range and seven in the Quadrilátero Ferrífero. To permit better visualisation of the results, the survey sites were classified according to their river basin: 20 in the Rio Doce basin, 12 in the Alto Rio Grande basin, 7 in the Rio Jequitinhonha basin, 5 in the Rio São Francisco basin, 5 in the Rio Paraíba do Sul basin, 2 in the Rio Paraguaçu basin, and 1 in each of the Rio das Contas, Rio Itanhém and Rio Itapemirim basins (Fig. 1B \& C).

The published floristic lists chosen for our analysis were produced by a variety of survey methods, including quadrats, point-centre quarter method, and general collecting ('non-systematic'). For surveys that included herbs, lianas, etc., only those species cited as arboreal by Oliveira-Filho (2006) were included. When species identification was uncertain (i.e. determined as 'cf.' or 'aff.') we included such taxa as belonging to the species referred to. Only lists with more than $90 \%$ of identified species were included.

Table 1 contains geographical coordinates and other information about the floristic survey for each locality, together with the codes by which they are cited in the figures. The data were compiled from the published floristic surveys, with the database 'TreeAtlan 2.0' (Oliveira-Filho, 2010) being used for missing data.

Two forms of multivariate analysis, one for clustering and the other for correspondence, were applied whereby the species registered in each of the 54 sites were first allotted to a presence and absence matrix. To facilitate the analysis, species present in only one area were then excluded (Ratter et al., 2003). A dendrogram was constructed using UPGMA (Unweighted Pair Group with Arithmetic Mean) for grouping, the simplest and most widely used method for this type of analysis (Pielou, 1984). Both Jaccard and Sørensen similarity indices, adjusted for binary data, were then applied, although only the former are reported since both indicated a similar pattern between areas. Detrended Correspondence Analysis (DCA) was applied to compare the patterns revealed, to determine to what extent the various analyses would result in congruent patterns. Detrended Correspondence Analysis is appropriate for such studies involving heterogenic and complex samples that reveal little change in a continuous gradient (Gauch, 1982; Pielou, 1984). The Multivariate Statistical Package (MVSP) program (Kovach, 2004) was used for the UPGMA and DCA analyses. The patterns generated by the analyses were considered as indirect measurements of modulating environmental factors (Gauch, 1982). Since the selected surveys are not suitable for

Mantiqueira. (B) Sites of the 54 surveys of arboreal species in the Atlantic Forest. Localities are cited according to the codes in Table 1 . The surveys at Linhares and Viçosa are represented by only one symbol. Legend: $\mathbf{\square}=$ Alto Rio Grande basin, $\square=$ Rio das Contas basin, $\boldsymbol{\Delta}=$ Rio Doce basin, $\nabla=$ Rio Itanhém basin, $\Delta=$ Rio Itapemirim basin, $\boldsymbol{O}=$ Rio Jequitinhonha basin, $\bigcirc=$ Rio Paraguaçu basin, $\bullet=$ Rio Paraíba do Sul basin, $\boldsymbol{\nabla}=$ Rio São Francisco basin. (C) River basin boundaries: $\mathrm{I}=$ Alto Rio Grande, II $=$ Rio das Contas, III $=$ Rio Doce, IV = Rio Itanhém, V = Rio Itapemirim, VI $=$ Rio Jequitinhonha, VII $=$ Rio Paraguaçu, VIII $=$ Rio Paraíba do Sul, IX = Rio São Francisco. 
TABLE 1. The 54 survey sites of arboreal species in the Atlantic Forest, with geographic, environmental and methodological information. The areas are listed alphabetically by basin and then by code

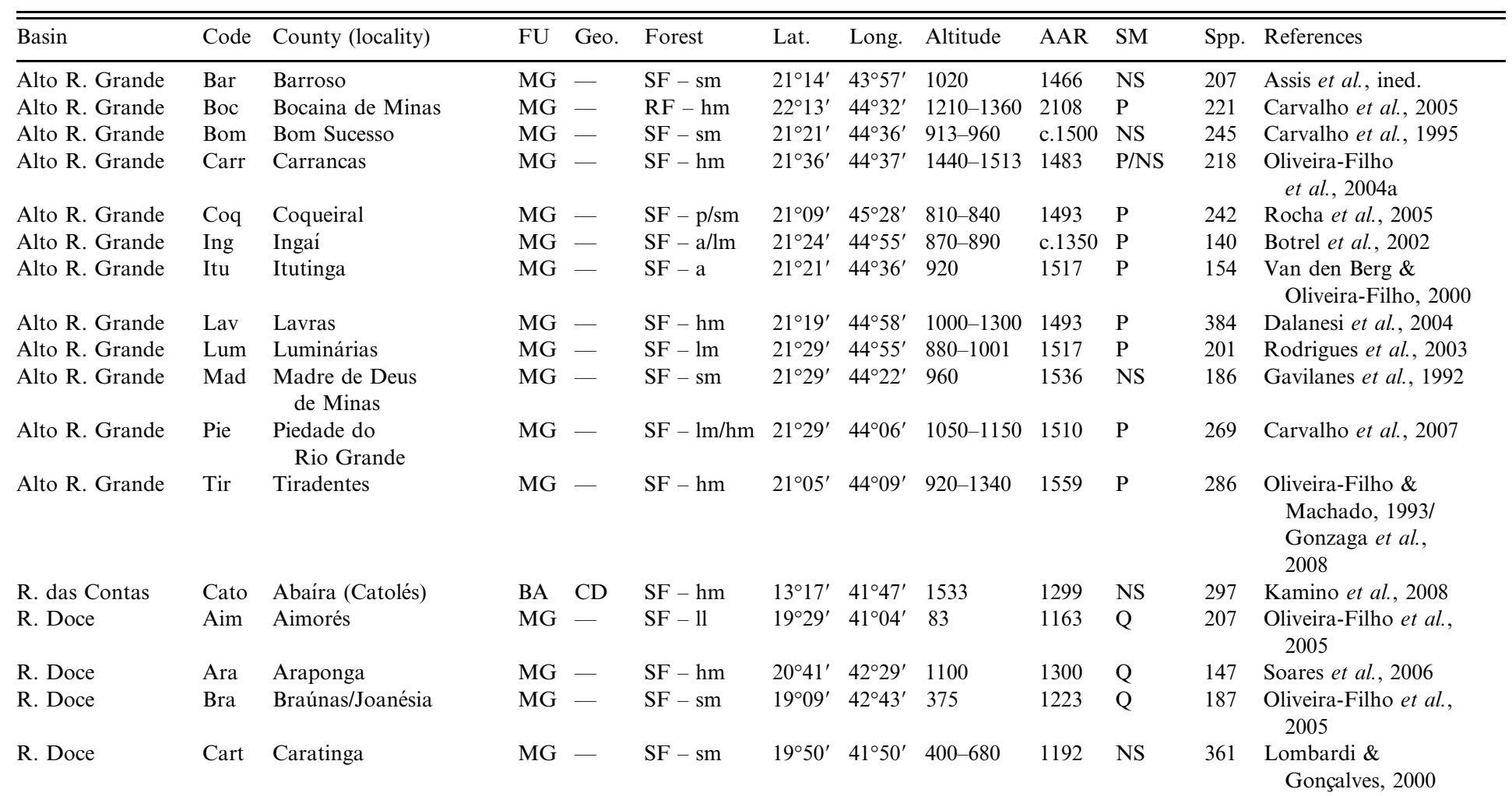


TABle 1. (Cont'd)

\begin{tabular}{|c|c|c|c|c|c|c|c|c|c|c|c|c|}
\hline R. Doce & Cata & $\begin{array}{l}\text { Catas Altas da } \\
\text { Noruega }\end{array}$ & MG & QF & $\mathrm{SF}-\mathrm{hm}$ & $20^{\circ} 36^{\prime}$ & $43^{\circ} 33^{\prime}$ & 1303 & 1310 & NS & 215 & Kamino et al., 2008 \\
\hline R. Doce & Gov & $\begin{array}{l}\text { Governador } \\
\text { Valadaris }\end{array}$ & MG & - & $\mathrm{SF}-11$ & $18^{\circ} 51^{\prime}$ & $42^{\circ} 01^{\prime}$ & 279 & 1114 & Q & 169 & $\begin{array}{l}\text { Oliveira-Filho et al., } \\
2005\end{array}$ \\
\hline R. Doce & Ital & $\begin{array}{l}\text { Itambé do Mato Dentro } \\
\text { (Serra do Cipó) }\end{array}$ & MG & MER & $\mathrm{SF}-\mathrm{lm}$ & $19^{\circ} 24^{\prime}$ & $43^{\circ} 24^{\prime}$ & $700-1100$ & 1462 & $\mathrm{Q} / \mathrm{NS}$ & 282 & Santos, 2009 \\
\hline R. Doce & Ita2 & Itambé do Mato Dentro & MG & - & $\mathrm{SF}-\mathrm{sm}$ & $19^{\circ} 26^{\prime}$ & $43^{\circ} 14^{\prime}$ & $610-630$ & 1460 & $\mathrm{P}$ & 198 & $\begin{array}{l}\text { Carvalho et al., 2000/ } \\
\text { Oliveira-Filho et al., } \\
\text { 2004b }\end{array}$ \\
\hline R. Doce & Lin1 & Linhares (CVRD) & ES & - & $\mathrm{RF}-11$ & $19^{\circ} 08^{\prime}$ & $39^{\circ} 56^{\prime}$ & 50 & 1224 & NS & 442 & Jesus \& Garcia, 1992 \\
\hline R. Doce & $\operatorname{Lin} 2$ & Linhares (FESARD) & ES & - & $\mathrm{RF}-\mathrm{a} / \mathrm{ll}$ & $19^{\circ} 08^{\prime}$ & $39^{\circ} 56^{\prime}$ & 50 & 1224 & $\mathrm{P} / \mathrm{NS}$ & 408 & Rolim et al., 2006 \\
\hline R. Doce & Mari & Mariana & MG & QF & $\mathrm{SF}-\mathrm{lm}$ & $20^{\circ} 23^{\prime}$ & $43^{\circ} 10^{\prime}$ & 710 & 1533 & Q & 289 & Oliveira-Filho et al., 2005 \\
\hline R. Doce & Marl & $\begin{array}{l}\text { Marliéria/ } \\
\text { Timóteo/Dionísio }\end{array}$ & MG & - & $\mathrm{SF}-\mathrm{sm}$ & $19^{\circ} 41^{\prime}$ & $42^{\circ} 38^{\prime}$ & $250-400$ & 1450 & NS & 186 & $\begin{array}{l}\text { Lombardi \& Gonçalves, } \\
2000\end{array}$ \\
\hline R. Doce & RioD & Rio Doce & MG & - & $\mathrm{SF}-\mathrm{sm}$ & $20^{\circ} 15^{\prime}$ & $42^{\circ} 54^{\prime}$ & 380 & 1297 & Q & 323 & Oliveira-Filho et al., 2005 \\
\hline R. Doce & SãoG & $\begin{array}{l}\text { São Gonçalo do } \\
\text { Rio Abaixo }\end{array}$ & MG & - & $\mathrm{SF}-\mathrm{sm} / \mathrm{lm}$ & $10^{\circ} 52^{\prime}$ & $43^{\circ} 20^{\prime}$ & $675-733$ & c. 1400 & Q & 257 & $\begin{array}{l}\text { Pedralli \& Teixeira, } \\
\text { 1997/Lopes } \text { et al., } 2009\end{array}$ \\
\hline R. Doce & SãoP & São Pedro do Suaçuí & MG & - & $\mathrm{SF}-\mathrm{sm}$ & $18^{\circ} 22^{\prime}$ & $42^{\circ} 36^{\prime}$ & 498 & 1185 & Q & 167 & Oliveira-Filho et al., 2005 \\
\hline R. Doce & StaB & Santa Bárbara & MG & QF & $\mathrm{SF}-\mathrm{sm}$ & $19^{\circ} 54^{\prime}$ & $43^{\circ} 22^{\prime}$ & 680 & 1365 & $\mathrm{Q}$ & 182 & Oliveira-Filho et al., 2005 \\
\hline R. Doce & Viçl & $\begin{array}{l}\text { Viçosa (Jd. Bot. - } \\
\text { UFV) }\end{array}$ & MG & - & $\mathrm{SF}-\mathrm{sm}$ & $20^{\circ} 45^{\prime}$ & $42^{\circ} 55^{\prime}$ & 700 & 1340 & $P$ & 156 & $\begin{array}{l}\text { Lopes et al., 2002/ } \\
\text { Ferreira-Júnior } \\
\text { et al., } 2007\end{array}$ \\
\hline R. Doce & Viç2 & $\begin{array}{l}\text { Viçosa (Mata da } \\
\text { Silvicultura) }\end{array}$ & MG & - & $\mathrm{SF}-\mathrm{sm}$ & $20^{\circ} 45^{\prime}$ & $42^{\circ} 55^{\prime}$ & $670-730$ & 1221 & $\mathrm{P}$ & 154 & $\begin{array}{l}\text { Meira-Neto \& } \\
\text { Martins, } 2002\end{array}$ \\
\hline R. Doce & Viç3 & $\begin{array}{l}\text { Viçosa (Mata da } \\
\text { Pedreira) }\end{array}$ & MG & - & $\mathrm{SF}-\operatorname{lm}$ & $20^{\circ} 45^{\prime}$ & $42^{\circ} 55^{\prime}$ & $730-870$ & 1221 & NS & 197 & Marangon et al., 2003 \\
\hline R. Doce & Viç4 & $\begin{array}{l}\text { Viçosa } \\
\text { (EPTEA - UFV) }\end{array}$ & MG & - & $\mathrm{SF}-\mathrm{sm}$ & $20^{\circ} 45^{\prime}$ & $42^{\circ} 55^{\prime}$ & 689 & 1221 & $\mathrm{P}$ & 161 & Silva et al., 2004 \\
\hline R. Itanhém & Mac & Machacalis & MG & - & $\mathrm{SF}-11$ & $17^{\circ} 11^{\prime}$ & $40^{\circ} 35^{\prime}$ & 278 & 1132 & $\mathrm{P}$ & 212 & Oliveira-Filho et al., 2005 \\
\hline R. Itapemirim & Cas & Castelo & ES & - & $\mathrm{RF}-1 \mathrm{l}$ & $20^{\circ} 37^{\prime}$ & $41^{\circ} 10^{\prime}$ & 100 & 1147 & $\mathrm{Q}$ & 285 & Oliveira-Filho et al., 2005 \\
\hline R. Jequitinhonha & Cha & $\begin{array}{l}\text { Carbonita } \\
\text { (Chapada de } \\
\text { São Domingos) }\end{array}$ & MG & SER & $\mathrm{SF}-\mathrm{lm}$ & $17^{\circ} 29^{\prime}$ & $43^{\circ} 08^{\prime}$ & 890 & 999 & Q & 200 & Oliveira-Filho et al., 2005 \\
\hline
\end{tabular}


TAB LE 1. (Cont'd)

\begin{tabular}{|c|c|c|c|c|c|c|c|c|c|c|c|c|}
\hline Basin & Code & County (locality) & $\mathrm{FU}$ & Geo. & Forest & Lat. & Long. & Altitude & AAR & SM & Spp. & References \\
\hline R. Jequitinhonha & Dia & Diamantina & MG & MER & $\mathrm{SF}-\mathrm{hm}$ & $18^{\circ} 14^{\prime}$ & $43^{\circ} 36^{\prime}$ & 1279 & 1406 & NS & 248 & Kamino et al., 2008 \\
\hline R. Jequitinhonha & Grã & Grão-Mogol & MG & SER & $\mathrm{SF}-\mathrm{sm} / \mathrm{lm}$ & $16^{\circ} 20^{\prime}$ & $43^{\circ} 00^{\prime}$ & $650-1100$ & 1035 & NS & 186 & $\begin{array}{l}\text { Pirani et al. (orgs.), } \\
\text { 2003, 2004, } 2006\end{array}$ \\
\hline R. Jequitinhonha & Lem & Leme do Prado & MG & SER & $\mathrm{SF}-\mathrm{lm}$ & $17^{\circ} 04^{\prime}$ & $42^{\circ} 43^{\prime}$ & 834 & 915 & Q & 227 & Oliveira-Filho et al., 2005 \\
\hline R. Jequitinhonha & Pos & Cristália (Posses) & MG & - & $\mathrm{SF}-\mathrm{sm}$ & $16^{\circ} 54^{\prime}$ & $42^{\circ} 46^{\prime}$ & 419 & 915 & $\mathrm{Q}$ & 224 & Oliveira-Filho et al., 2005 \\
\hline R. Jequitinhonha & RioV & Rio Vermelho & MG & MER & $\mathrm{SF}-\mathrm{hm}$ & $18^{\circ} 03^{\prime}$ & $43^{\circ} 00^{\prime}$ & 1200 & 1081 & NS & 75 & Pirani et al., 1994 \\
\hline R. Jequitinhonha & Vir & Virgem da Lapa & MG & - & $\mathrm{SF}-\mathrm{sm}$ & $16^{\circ} 43^{\prime}$ & $42^{\circ} 13^{\prime}$ & 312 & 812 & $\mathrm{Q}$ & 148 & Oliveira-Filho et al., 2005 \\
\hline R. Paraguaçu & Muc & Mucugê & BA & $\mathrm{CD}$ & $\mathrm{SF}-\mathrm{hm}$ & $13^{\circ} 00^{\prime}$ & $41^{\circ} 22^{\prime}$ & 1038 & 1155 & NS & 163 & Kamino et al., 2008 \\
\hline R. Paraguaçu & Pal & Palmeiras & BA & $\mathrm{CD}$ & $\mathrm{SF}-\operatorname{lm}$ & $12^{\circ} 27^{\prime}$ & $41^{\circ} 27^{\prime}$ & 1043 & 1301 & NS & 209 & Kamino et al., 2008 \\
\hline R. Paraíba do Sul & Carn & Carangola & MG & - & $\mathrm{SF}-\mathrm{sm}$ & $20^{\circ} 44^{\prime}$ & $42^{\circ} 02^{\prime}$ & 408 & 1259 & $\mathrm{Q}$ & 288 & Oliveira-Filho et al., 2005 \\
\hline R. Paraíba do Sul & Jui & Juiz de Fora & MG & - & $\mathrm{SF}-\mathrm{sm}$ & $21^{\circ} 45^{\prime}$ & $43^{\circ} 21^{\prime}$ & 923 & 1470 & NS & 176 & Pifano et al., 2007 \\
\hline R. Paraíba do Sul & Mir & Miraí & MG & - & $\mathrm{SF}-11$ & $21^{\circ} 32^{\prime}$ & $42^{\circ} 36^{\prime}$ & 280 & 1237 & Q & 272 & Oliveira-Filho et al., 2005 \\
\hline R. Paraíba do Sul & SãoF & $\begin{array}{l}\text { São Francisco do } \\
\text { Itabapoana }\end{array}$ & $\mathrm{RJ}$ & - & $\mathrm{SF}-11$ & $21^{\circ} 24^{\prime}$ & $41^{\circ} 04^{\prime}$ & 20 & 1084 & $\mathrm{P}$ & 83 & Silva \& Nascimento, 2001 \\
\hline R. Paraíba do Sul & Vis & $\begin{array}{l}\text { Resende (Visconde } \\
\text { de Mauá) }\end{array}$ & RJ & - & $\mathrm{MF}-\mathrm{hm}$ & $22^{\circ} 20^{\prime}$ & $44^{\circ} 36^{\prime}$ & $1150-1350$ & 2459 & NS & 187 & Pereira et al., 2006 \\
\hline R. São Francisco & $\mathrm{BH}$ & Belo Horizonte & MG & QF & $\mathrm{SF}-\mathrm{a}$ & $22^{\circ} 00^{\prime}$ & $43^{\circ} 58^{\prime}$ & 1086 & 1492 & $\mathrm{P}$ & 97 & Meyer et al., 2004 \\
\hline R. São Francisco & Com & Congonhas & MG & $\mathrm{QF}$ & $\mathrm{SF}-\operatorname{lm}$ & $20^{\circ} 30^{\prime}$ & $43^{\circ} 44^{\prime}$ & 968 & 1297 & NS & 269 & Kamino et al., 2008 \\
\hline R. São Francisco & $\mathrm{Jab}$ & $\begin{array}{l}\text { Santana do Riacho/ } \\
\text { Jaboticatubas }\end{array}$ & MG & MER & $\mathrm{SF}-\mathrm{a} / \mathrm{hm}$ & $19^{\circ} 13^{\prime}$ & $43^{\circ} 32^{\prime}$ & 1367 & 1601 & $\mathrm{Q} / \mathrm{P} / \mathrm{NS}$ & 229 & $\begin{array}{l}\text { Meguro et al., 1996/ } \\
\text { Campos, } 1995\end{array}$ \\
\hline R. São Francisco & Nov & Nova Lima & MG & QF & $\mathrm{SF}-\operatorname{lm}$ & $19^{\circ} 58^{\prime}$ & $43^{\circ} 54^{\prime}$ & 963 & 1451 & Q & 209 & Kamino et al., 2008 \\
\hline R. São Francisco & Our & Ouro Preto & MG & QF & $\mathrm{SF}-\mathrm{hm}$ & $20^{\circ} 23^{\prime}$ & $43^{\circ} 34^{\prime}$ & $1280-1450$ & c. 1600 & $P$ & 198 & $\begin{array}{l}\text { Pedralli et al., 1997/ } \\
\text { Werneck et al., } 2000\end{array}$ \\
\hline
\end{tabular}

FU = Federal Unit; Geo. = geomorphology; Lat. = latitude; Long. = longitude; AAR = average annual rainfall; SM = sampling methodology; Spp. = number of species; R. = River; QF = Quadrilátero Ferrífero; MER = Meridional Espinhaço Range; SER = Septentrional Espinhaço Range; CD = Chapada Diamantina; $\mathrm{SF}=$ semideciduous forest; $\mathrm{RF}=$ rain forest; $\mathrm{MF}=$ mixed forest; $\mathrm{p}=$ paludal; $\mathrm{a}=$ alluvial; $1 \mathrm{l}=$ lowlands; $\mathrm{sm}=\mathrm{sub}-\mathrm{montane}$; lm $=$ low-mountain; hm = highmountain; $\mathrm{Q}=$ quadrat; $\mathrm{P}=$ parcel; NS = non-systematic. There is space in the column 'Geomorphology' only for localities pertaining to the Espinhaço Range and the Quadrilátero Ferrífero. 
making conclusions about geographic distributions, as they are too limited, the discussion on species distributions was supplemented with data from recent literature.

Jaccard similarity indices were applied to the Espinhaço and Quadrilátero Ferrífero sites to better understand phytogeographic relationships between them. Furthermore, in the group formed exclusively by forest areas inside the campos rupestres of Espinhaço in the cluster (group 1) and correspondence analyses, those species with more than $50 \%$ occurrence were indicated, in order to distinguish typical species and emphasise vegetation features.

\section{RESULTS}

The cluster analysis (UPGMA) produced four main groups (Fig. 2):

- Group 1 includes forests located throughout the entire Espinhaço Range, i.e. in the Meridional (Diamantina, Santana do Riacho/Jaboticatubas, Rio Vermelho) and Septentrional (Grão-Mogol) zones, as well as in the southern Chapada Diamantina (Palmeiras, Mucugê, Catolés). Other areas in the Espinhaço were not included in this group (see below).

- Group 2 includes forest areas in the Rio Jequitinhonha basin. Chapada de São Domingos and Leme do Prado, located in the Septentrional Espinhaço, are part of this group. Note that although the Diamantina, Serra do Ambrósio and GrãoMogol sites are situated at the upper drainage of this basin, their affinity is rather with group 1.

- Group 3 includes three distinct subgroups, one (3.1) predominantly of forest areas of the Alto Rio Grande basin; another (3.2) of upland forests (altitude $>1100 \mathrm{~m}$, sensu Oliveira-Filho \& Fontes, 2000) occurring in the Quadrilátero Ferrífero, at Catas Altas da Noruega, Congonhas, Mariana and Nova Lima (note that Ouro Preto and Belo Horizonte, also situated in the Quadrilátero Ferrífero, are isolated from this group); and a third subgroup (3.3) comprising upland forests of the Serra da Mantiqueira (Visconde de Mauá, Carrancas, Bocaina de Minas).

- Group 4 includes forest areas in the Rio Paraíba do Sul (Juiz de Fora, Carangola, Miraí) and Rio Doce basins, as well as one in the Rio Itanhém basin and one in the Rio Itapemirim basin. Itambé do Mato Dentro (located in the Meridional Espinhaço) and Santa Bárbara (located in the Quadrilátero Ferrífero) are also in this group.

In the correspondence analysis, axes 1 and 2 resolved only $11 \%$ of the variation (7.3\% and 3.8\%, respectively). According to Ter Braak (1995), such low percentages are intermediary, thereby indicating moderate gradients, with some of the species distributed at all sites, while others are exclusive to certain sites (Fig. 3).

The patterns revealed in this analysis are partially congruent with results from the cluster analysis. Areas of the Espinhaço located in group 1 in the cluster analysis are at the extreme right of the DCA graph, but with considerable variation as determined by 


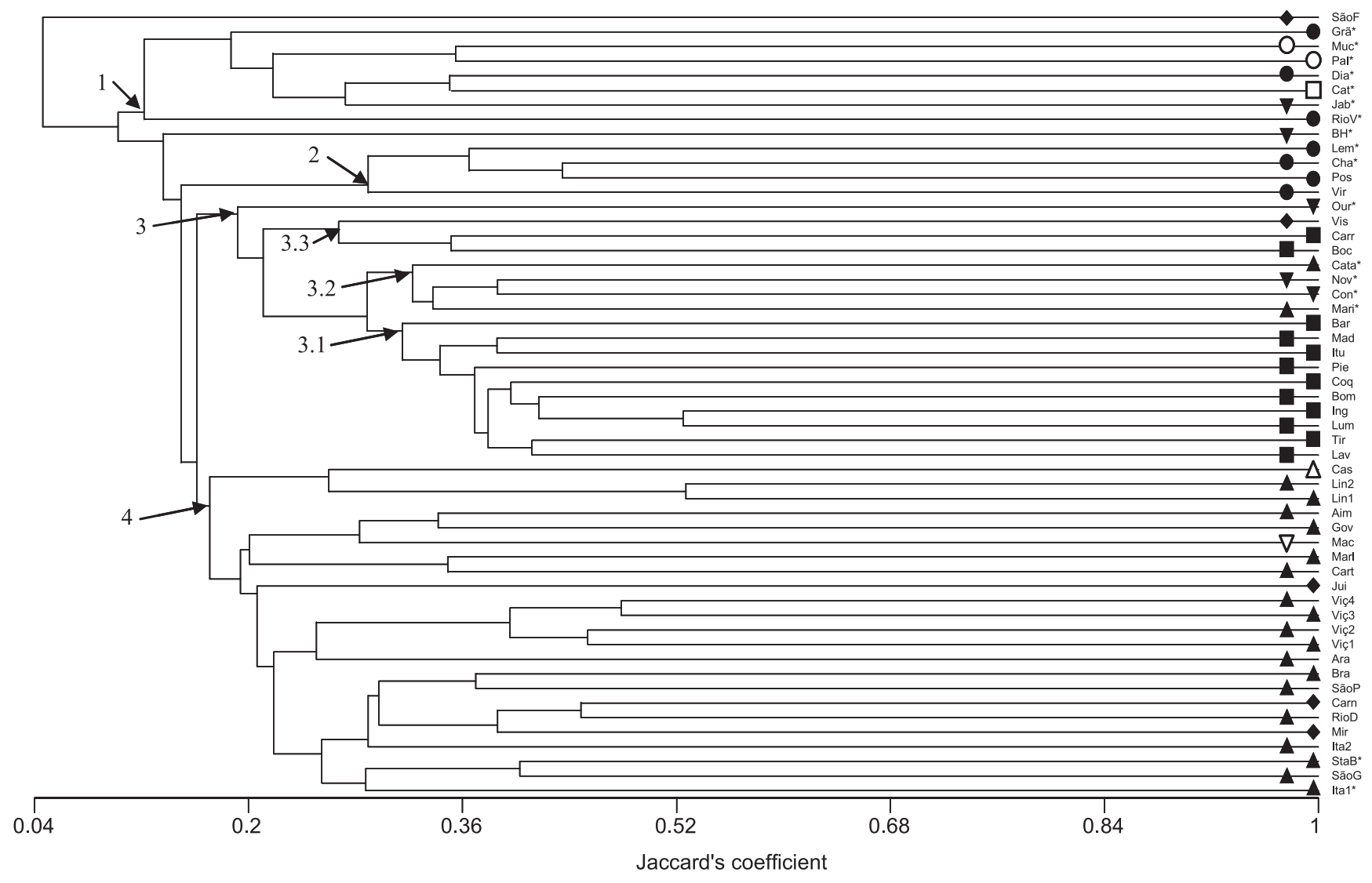

FIg. 2. UPGMA dendrogram, based on the Jaccard index, comparing 54 surveys of arboreal species in the Atlantic Forest. Localities are cited according to the codes in Table 1. The symbols on the terminal branches correspond to the basin to which surveyed areas pertain. Groups discussed in the text are highlighted. Localities in the Quadrilátero Ferrífero and Espinhaço Range are marked with an asterisk (*). Legend: $\mathbf{\square}=$ Alto Rio Grande basin, $\square=$ Rio das Contas basin, $\boldsymbol{\Delta}=$ Rio Doce basin, $\nabla=$ Rio Itanhém basin, $\Delta=$ Rio Itapemirim basin, $\bullet=$ Rio Jequitinhonha basin, $\bigcirc=$ Rio Paraguaçu Basin, $\bullet=$ Rio Paraíba do Sul basin, $\boldsymbol{\nabla}=$ Rio São Francisco basin. 


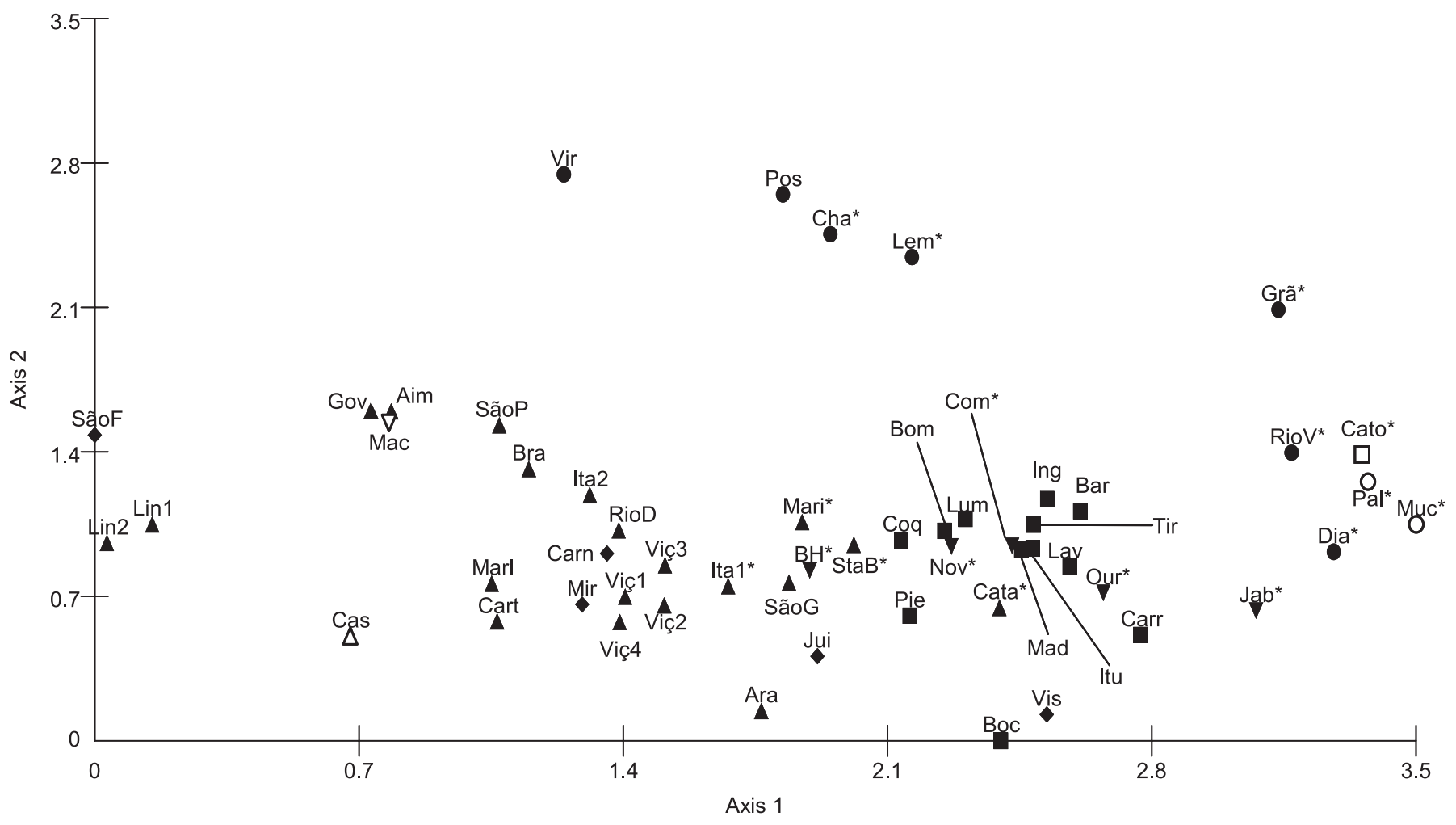

FIG. 3. Graph of Detrended Correspondence Analysis (DCA), comparing 54 surveys of arboreal species in the Atlantic Forest. Localities are cited according to the codes in Table 1. Localities in the Quadrilátero Ferrífero and the Espinhaço Range are marked with an asterisk $(*)$. Legend: $\mathbf{\square}=$ Alto Rio Grande basin, $\square=$ Rio das Contas basin, $\boldsymbol{\Lambda}=$ Rio Doce basin, $\nabla=$ Rio Itanhém basin, $\Delta=$ Rio Itapemirim basin, $\boldsymbol{\bullet}$ = Rio Jequitinhonha basin, $\bigcirc=$ Rio Paraguaçu basin, $\bullet=$ Rio Paraíba do Sul basin, $\boldsymbol{\nabla}=$ Rio São Francisco basin. 
axis 2. Such variation may be related to latitude, since the more southern areas are placed in the lower part (except for Grão-Mogol). The influence of latitude can also be inferred for those areas in the Jequitinhonha basin (group 2 in the cluster analysis) that are located at higher latitudes, and present higher values with regard to axis 2 . Although presenting high variation in relation to axis 1 , this group is well differentiated by axis 2 .

Another grouping similar to that revealed by cluster analysis, and linked mainly to axis 1, comprises the forest areas of the Rio Grande basin (located to the right of the figure), close to some areas of the Quadrilátero Ferrífero (Catas Altas da Noruega, Congonhas, Nova Lima and Ouro Preto) and all areas of the Serra da Mantiqueira (group 3 in the cluster analysis). Forest areas in basins that irrigate eastern Minas Gerais State (group 4 in the cluster analysis), on the other hand, are concentrated to the left of the figure, and show marked variation on axis 2. At the intersection of these two groups are the areas of Santa Bárbara, São Gonçalo do Rio Abaixo and Mariana, in the Rio Doce basin, and Belo Horizonte, in the Rio São Francisco basin (all of them included in the Quadrilátero Ferrífero except São Gonçalo), and Coqueiral and Piedade do Rio Grande, in the Alto Rio Grande basin. Subgroups 3.1, 3.2 and 3.3 were not discernible in the correspondence analysis.

The Jaccard similarity index values for sites in the Espinhaço Range and Quadrilátero Ferrífero (Table 2) were mostly less than 25\% (i.e. low sensu MuellerDombois \& Ellenberg, 1974). Consequently, there was no general similarity among surveys, although there were small subgroups, some of which were revealed through multivariate analysis. The greatest similarities are indicated in bold type in Table 2 . Those species with more than $50 \%$ occurrence in the group formed exclusively by forest areas inside the campos rupestres of Espinhaço, delimited by cluster (group 1) and correspondence analysis, are indicated in Table 3.

\section{DiscusSiON}

\section{Phytogeographic patterns in the Atlantic Semideciduous Forests}

The relatively high congruence of the patterns arising from the two analyses (cluster and correspondence) gives us confidence in the strength of the data and allows us to generate hypotheses regarding potential causes.

The analysis separated the Alto Rio Grande basin forests, group 3.1, from those of the Rio Jequitinhonha basin (group 2), and those of the Rio Doce and Rio Paraíba do Sul basins (group 4) (Figs 2, 3). This floristic pattern probably reflects the level of humidity throughout the year in these basins, since humidity plays a fundamental role in phytogeographic patterns in the Atlantic Forest (Torres et al., 1997; Ivanauskas et al., 2000; Oliveira-Filho \& Fontes, 2000; Oliveira-Filho et al., 2005, 2006; Durigan et al., 2008).

The seasonal areas in the Paraíba do Sul and Rio Doce basins have higher rainfall than those in the Alto Rio Grande basin and other seasonal areas. In the Paraíba do Sul basin, the Serra da Mantiqueira (see Fig. 1A \& C) presents a barrier to oceanic 
TA B LE 2. Similarity index (Jaccard) between localities in the Espinhaço Range and the Quadrilátero Ferrífero. Similarities $>25 \%$ are outstanding. For explanation of locality codes see Table 1

\begin{tabular}{|c|c|c|c|c|c|c|c|c|c|c|c|c|c|c|c|c|c|}
\hline Code & Ita1 & $\mathrm{BH}$ & Our & RioV & $\mathrm{Jab}$ & Grã & StaB & Lem & Cha & Mari & Cato & Pal & Muc & Dia & Com & Nov & Cata \\
\hline Ita1 & 1 & & & & & & & & & & & & & & & & \\
\hline $\mathrm{BH}$ & 0.12581 & 1 & & & & & & & & & & & & & & & \\
\hline Our & 0.14948 & 0.14583 & 1 & & & & & & & & & & & & & & \\
\hline RioV & 0.07792 & 0.05921 & 0.07950 & 1 & & & & & & & & & & & & & \\
\hline $\mathrm{Jab}$ & 0.19059 & 0.08392 & 0.22222 & 0.16270 & 1 & & & & & & & & & & & & \\
\hline Grã & 0.12343 & 0.07422 & 0.10714 & 0.14667 & 0.16619 & 1 & & & & & & & & & & & \\
\hline StaB & 0.27089 & 0.10656 & 0.15773 & 0.09052 & 0.17201 & 0.13975 & 1 & & & & & & & & & & \\
\hline Cha & 0.18653 & 0.12992 & 0.11628 & 0.09312 & 0.12032 & 0.15315 & 0.17702 & 0.36129 & 1 & & & & & & & & \\
\hline Mari & 0.29245 & 0.14939 & 0.17037 & 0.07784 & 0.17824 & 0.10748 & 0.27793 & 0.26733 & 0.26563 & 1 & & & & & & & \\
\hline Cato & 0.13636 & 0.05988 & 0.13602 & 0.10855 & 0.22418 & 0.24586 & 0.14653 & 0.18689 & 0.16625 & 0.16913 & 1 & & & & & & \\
\hline Pal & 0.12469 & 0.04869 & 0.10234 & 0.11915 & 0.16056 & 0.17081 & 0.11712 & 0.14958 & 0.11782 & 0.11655 & 0.34911 & 1 & & & & & \\
\hline Muc & 0.08967 & 0.02679 & 0.08638 & 0.05446 & 0.11043 & 0.12371 & 0.08784 & 0.12308 & 0.08654 & 0.07789 & 0.26875 & 0.35510 & 1 & & & & \\
\hline Dia & 0.16038 & 0.07000 & 0.17087 & 0.13858 & 0.32070 & 0.22581 & 0.16011 & 0.17829 & 0.13757 & 0.16854 & 0.35054 & 0.23324 & 0.18790 & 1 & & & \\
\hline Com & 0.22695 & 0.17172 & 0.22590 & 0.09603 & 0.21827 & 0.11250 & 0.21884 & 0.22278 & 0.20263 & 0.33741 & 0.16964 & 0.10565 & 0.08696 & 0.21535 & 1 & & \\
\hline Nov & 0.24603 & 0.19522 & 0.21779 & 0.08846 & 0.19337 & 0.13429 & 0.25240 & 0.20833 & 0.17192 & 0.33780 & 0.16098 & 0.10744 & 0.06024 & 0.19086 & 0.38643 & 1 & \\
\hline
\end{tabular}


TABLE 3. Species with more than $50 \%$ occurrence in the seven localities in group 1 of the cluster analysis (listed alphabetically)

Species with four occurrences: Anadenanthera colubrina (Vell.) Brenan, Antonia ovata Pohl, Blepharocalyx salicifolius (Kunth) O.Berg, Calliandra asplenioides (Nees) Renvoize, Casearia eichleriana Sleumer, Cordiera elliptica (Cham.) Kuntze, Cyathea phalerata Mart., Cybianthus glaber A.DC., Dalbergia miscolobium Benth., Faramea nigrescens Mart., Ficus pertusa L.f., Gaylussacia brasiliensis (Spreng.) Meisn., Gochnatia polymorpha (Less.) Cabrera, Guapira graciliflora (Schmidt) Lundell, Guatteria rupestris Mello-Silva \& Pirani, Handroanthus ochraceus (Cham.) Mattos, Hymenaea stigonocarpa Mart. ex Hayne, Ilex lundii Warm., Lafoensia vandelliana Cham. \& Schltdl., Lamanonia ternata Vell., Leandra aurea (Cham.) Cogn., Leandra melastomoides Raddi, Marlierea clausseniana (O.Berg) Kiaersk., Marlierea laevigata (DC.) Kiaersk., Miconia theaezans (Bonpl.) Cogn., Moquinia racemosa (Spreng.) DC., Myrceugenia alpigena (DC.) Landrum, Myrcia blanchetiana (O.Berg) Mattos, Myrcia mutabilis (O.Berg) N.Silveira, Myrcia reticulosa Miq., Myrcia venulosa DC., Myrciaria floribunda (H.West ex Willd.) O.Berg, Myrsine venosa A.DC., Ocotea lancifolia (Schott) Mez, Ocotea oppositifolia S.Yasuda, Ocotea pomaderroides (Meisn.) Mez, Ouratea semiserrata (Mart. \& Nees) Engl., Persea splendens Meisn., Plenckia populnea Reissek, Posoqueria latifolia (Rudge) Roem. \& Schult., Protium brasiliense (Spreng.) Engl., Protium spruceanum (Benth.) Engl., Richeria grandis Vahl, Roupala rhombifolia Mart. ex Meisn., Siparuna guianensis Aubl., Siphoneugena densiflora O.Berg, Solanum cladotrichum Dunal, Styrax camporum Pohl, Styrax rotundatus (Perkins) P.W.Fritsch, Terminalia glabrescens Mart., Tibouchina fissinervia (Schrank \& Mart. ex DC.) Cogn., Vantanea compacta (Schnizl.) Cuatrec., Vitex polygama Cham., Vochysia emarginata Vahl, Vochysia pyramidalis Mart., Vochysia thyrsoidea Pohl

Species with five occurrences: Agarista oleifolia (Cham.) G.Don, Bowdichia virgilioides Kunth, Byrsonima sericea DC., Casearia sylvestris Sw., Clethra scabra Pers., Copaifera langsdorffii Desf., Cordiera concolor (Cham.) Kuntze, Cupania paniculata Cambess., Cyathea corcovadensis (Raddi) Domin, Cyathea delgadii Sternb., Cyathea villosa Willd., Drimys brasiliensis Miers, Emmotum nitens (Benth.) Miers, Eugenia florida DC., Geonoma brevispatha Barb.Rodr., Hedyosmum brasiliense Miq., Hirtella glandulosa Spreng., Ilex dumosa Reissek, Kielmeyera petiolaris Mart., Miconia chartacea Triana, Miconia rimalis Naudin, Myrcia amazonica DC., Ocotea velloziana (Meisn.) Mez, Pouteria ramiflora (Mart.) Radlk., Protium heptaphyllum (Aubl.) Marchand, Psidium guineense Sw., Psychotria vellosiana Benth., Roupala montana Aubl., Senna macranthera (Collad.) H.S.Irwin \& Barneby, Simarouba amara Aubl., Symplocos crenata (Vell.) Mattos, Symplocos nitens (Pohl) Benth., Tapirira guianensis Aubl., Ternstroemia carnosa Cambess., Tibouchina candolleana (Mart. ex DC.) Cogn., Vantanea obovata (Nees \& Mart.) Benth.

Species with six occurrences: Cabralea canjerana (Vell.) Mart., Calophyllum brasiliense Cambess., Dictyoloma vandellianum A.Juss., Erythroxylum vaccinifolium Mart., Esenbeckia grandiflora Mart., Eugenia punicifolia (Kunth) DC., Guatteria sellowiana Schltdl., Macropeplus ligustrinus (Tul.) Perkins, Maprounea guianensis Aubl., Micropholis gnaphaloclados (Mart.) Pierre, Myrcia guianensis (Aubl.) DC., Myrcia tomentosa (Aubl.) DC., Myrsine guianensis (Aubl.) Kuntze, Myrsine umbellata Mart., Ocotea percoriacea (Meisn.) Kosterm., Ocotea spixiana (Nees) Mez, Ouratea floribunda Engl., Pera glabrata (Schott) Poepp. ex Baill., Piper cernuum Vell., Prunus myrtifolia (L.) Urb., Sapium glandulosum (L.) Morong, Trembleya parviflora (D.Don) Cogn., Vochysia tucanorum Mart., Zanthoxylum rhoifolium Lam.

Species with seven occurrences: Alchornea triplinervia (Spreng.) Müll.Arg., Andira fraxinifolia Benth., Casearia arborea (Rich.) Urb., Guapira opposita (Vell.) Reitz, Humiria balsamifera Aubl., Myrcia splendens (Sw.) DC., Tapirira obtusa (Benth.) J.D.Mitch. 
humidity, promoting orographic rain in the region. In the Rio Doce basin, most of the humidity is due to the lowlands at the river-mouth (see Fig. 1C) which permit the penetration of oceanic moisture deeply into the continental interior, resulting in a gradual transition to a seasonal climate, and a less severe dry season (Campos, 1926; Oliveira-Filho \& Fontes, 2000; Oliveira-Filho et al., 2005).

The relatively high humidity throughout the year permits the occurrence inland of species that are intolerant to higher seasonality. In areas where climatic seasonality is more pronounced (e.g. Alto Rio Grande and the Atlantic Plateau in São Paulo State) there is a greater contrast in floristic composition between wet and aseasonal and contiguous seasonal areas, due to the more abrupt change in climate (Torres et al., 1997; Ivanauskas et al., 2000; Oliveira-Filho \& Fontes, 2000; Oliveira-Filho et al., 2005; Durigan et al., 2008). This increased humidity allows some species to occur both in the semideciduous forests of the Doce and Paraíba do Sul river basins and in rain forests (see data in Oliveira-Filho et al., 2006 for the eastern part of the Atlantic Forest). Rolim et al. (2006) claimed that there is more floristic affinity between rain forest of coastal areas of Espírito Santo State and contiguous inland semideciduous forests than between the former and rain forest further to the south. A number of species illustrate this pattern. One example is Tetrastylidium grandifolium (Baill.) Sleumer (Olacaceae), which occurs in rain forests from the south of São Paulo State to the south of Bahia and only in semideciduous forests of the Paraíba do Sul and Rio Doce basins (Sleumer, 1984; Oliveira-Filho, 2006). Other species show a similar pattern (by family):

- Annonaceae: Trigynaea oblongifolia Schltdl. (Maas et al., 2001; Oliveira-Filho, 2006);

- Arecaceae: Polyandrococos caudescens (Mart.) Barb.Rodr. (Henderson et al., 1995; Oliveira-Filho, 2006);

- Bignoniaceae: Paratecoma peroba (Record) Kuhlm. (Gentry, 1992);

- Burseraceae: Crepidospermum atlanticum Daly (Daly, 2002; Oliveira-Filho, 2006);

- Celastraceae: Maytenus brasiliensis Mart. (Joffily \& Vieira, 2006; Oliveira-Filho, 2006);

- Chrysobalanaceae: Licania belemii Prance (Prance, 1989; Oliveira-Filho, 2006);

- Clusiaceae: Tovomita leucantha (Schltdl.) Planch. \& Triana (Oliveira-Filho, 2006);

- Lauraceae: Nectandra leucantha Nees (Rohwer, 1993), Nectandra psammophila Nees (Rohwer, 1993), Ocotea beyrichii (Nees) Mez (Baitello et al., 2003; OliveiraFilho, 2006), Urbanodendron verrucosum (Nees) Mez (Rohwer, 1988);

- Malvaceae: Eriotheca macrophylla (K.Schum.) A.Robyns (Oliveira-Filho, 2006);

- Melastomataceae: Miconia budlejoides Triana (Oliveira-Filho, 2006);

- Moraceae: Helicostylis tomentosa (Poepp. \& Endl.) Rusby (Berg, 1972; OliveiraFilho, 2006);

- Myrtaceae: Campomanesia laurifolia Gardner (Landrum, 1986; Oliveira-Filho, 2006), Myrcia anceps (Spreng.) O.Berg (Oliveira-Filho, 2006);

- Rubiaceae: Rudgea reticulata Benth. (Zappi, 2003); 
- Rutaceae: Pilocarpus giganteus Engl. (Skorupa, 1996);

- Salicaceae: Banara kuhlmannii (Sleumer) Sleumer (Sleumer, 1980);

- Sapotaceae: Chrysophyllum imperiale (Linden ex Koch \& Fintelm.) Benth. \& Hook.f., Pouteria microstrigosa T.D.Penn. (Pennington, 1990).

The distribution of some species also extends to seasonal areas in the Itanhém and Jequitinhonha river basins, which have a similar relief (see Fig. 1C), and thus similar rainfall, to that of the Rio Doce basin. Examples include (by family):

- Achariaceae: Carpotroche brasiliensis (Raddi) Endl. (Sleumer, 1980; OliveiraFilho, 2006);

- Anacardiaceae: Thyrsodium spruceanum Salzm. ex Benth. (Mitchell \& Daly, 1993; Oliveira-Filho, 2006);

- Annonaceae: Bocagea longipedunculata Mart., Duguetia chrysocarpa Maas (Maas et al., 2001; Oliveira-Filho, 2006);

- Arecaceae: Astrocaryum aculeatissimum (Schott) Burret (Henderson et al., 1995; Oliveira-Filho, 2006);

- Combretaceae: Buchenavia hoehneana N.F.Mattos (Oliveira-Filho, 2010);

- Euphorbiaceae: Joannesia princeps Vell., Senefeldera verticillata (Vell.) Croizat (Oliveira-Filho, 2006);

- Malvaceae: Sterculia curiosa (Vell.) Taroda (Oliveira-Filho, 2010);

- Rubiaceae: Genipa infundibuliformis Zappi \& Semir (Zappi et al., 1995; OliveiraFilho, 2006).

This higher rainfall also accounts for the similarity in floristic composition at Machacalis (Rio Itanhém basin) and Aimorés and Governador Valadares (Rio Doce basin). However, the climate in the more interior of these basins is influenced by the Atlantic Equatorial air mass (hot and dry) during a large part of the year, giving a marked seasonality. Thus, the penetration of humidity towards the continental interior is limited, and the relatively high humidity, as seen in Machacalis, occurs only in the more easterly areas of the basins.

This climate pattern probably exerts an influence on the group formed by areas in the Jequitinhonha basin, all of which lie towards the interior of the basin (group 2 in the cluster analysis). Arboreal species that are typical of the dry climate of the Caatinga domain occur at these sites. Amongst these are (by family):

- Anacardiaceae: Cyrtocarpa caatingae J.D.Mitch. \& Daly (Oliveira-Filho, 2006);

- Burseraceae: Commiphora leptophloeos (Mart.) J.B.Gillet (Gillet, 1980; OliveiraFilho, 2006);

- Cactaceae: Cereus jamacaru DC. (Oliveira-Filho, 2006);

- Leguminosae-Mimosoideae: Acacia spp., Blanchetiodendron blanchetii (Benth.) Barneby \& J.W.Grimes (Queiroz, 2009);

- Rhamnaceae: Ziziphus joazeiro Mart. (Lima, 2000). 
The seasonal areas of Alto Rio Grande, which are situated on the opposite slope of the Serra da Mantiqueira, have lower rainfall mainly because Atlantic humidity is impeded by the Serra do Mar scarps, as well as by the Serra da Mantiqueira itself (see Fig. 1A \& C). Even so, seasonal areas in the Alto Rio Grande have some floristic similarities with the adjacent higher rainfall areas situated on top of the Serra da Mantiqueira, as can be seen in group 3 (subgroups 3.1 and 3.3) in the UPGMA analysis. However, moving westwards, there is a rapid increase in seasonality, reflected in the transition from the Atlantic Forest to the Cerrado domains which occurs throughout the mid-part of the basin (see maps of the IBGE, 1993; Oliveira-Filho, 2006). Durigan et al. (2008) encountered a similar pattern in their analysis of forest fragments on the Paulistano Plateau, part of the Atlantic Plateau located immediately to the interior of the Serra do Mar heights. They noted that the flora of the southern area (more humid and facing the ocean) shows a greater similarity with rain forests, whereas to the north (less humid and facing the interior) the similarity is with semideciduous forests and cerrado. Thus, even in neighbouring areas, the decrease in humidity related to relief exerts a marked influence on floristic composition.

The following are some common species of the Cerrado domain which occur in the semideciduous forests of the Alto Rio Grande basin but are rare or absent in forest areas of the Rio Paraíba do Sul and Rio Doce basins:

- Erythroxylaceae: Erythroxylum daphnites Mart. (Mendonça \& Amaral Júnior, 2002; Oliveira-Filho, 2006);

- Lauraceae: Nectandra gardneri Meisn. (Rohwer, 1993; Oliveira-Filho, 2006);

- Leguminosae-Mimosoideae: Enterolobium gummiferum (Mart.) J.F.Macbr. (Oliveira-Filho, 2006), Stryphnodendron adstringens (Mart.) Coville (Oliveira-Filho, 2006; Scalon, 2007);

- Leguminosae-Papilionoideae: Dalbergia miscolobium Benth. (Carvalho, 1997; Oliveira-Filho, 2006), Holocalyx balansae Micheli (Oliveira-Filho, 2006);

- Malvaceae: Luehea paniculata Mart. \& Zucc. (Oliveira-Filho, 2006), Pseudobombax longiflorum (Mart. \& Zucc.) A.Robyns (Oliveira-Filho, 2006; Duarte et al., 2007);

- Myrtaceae: Eugenia klotzschiana O.Berg (Oliveira-Filho, 2006).

Several authors have noted the influence of altitude on floristic similarity between areas of the Atlantic Forest domain (Oliveira-Filho et al., 1994; Torres et al., 1997; Ivanauskas et al., 2000). In the current study altitude was not found to be an important factor for similarity between the semideciduous forests; in general, most of the floristic similarities revealed (in both cluster and correspondence analyses) can be explained by the influence of relief on Atlantic humidity. Furthermore, montane areas, such as Araponga $(1100 \mathrm{~m})$ and Itambé do Mato Dentro (Serra do Cipó $700-1100 \mathrm{~m}$ ), are grouped together with lowland forest areas, such as Miraí, Rio Doce and Carangola, at 280, 380 and 408 m, respectively (Figs 2, 3; Table 1).

Moreover, according to Oliveira-Filho et al. (2006), the floristic similarity of some montane areas (e.g. areas in the Alto Rio Grande, the Atlantic Plateau), supposedly 
associated with altitude, may be more linked to the proximity of these areas to the coast when compared with drier sub-montane areas further inland. The floristic differences between these montane and sub-montane areas may be more related to differences in seasonality than to altitude.

Nevertheless, it should be noted that our analysis revealed the influence of altitude on groups formed by the more upland areas of the Espinhaço Range, Serra da Mantiqueira and the Quadrilátero Ferrífero (Figs 2, 3; Table 1; see discussion below). In particular, the floristic similarity shown by areas of the Quadrilátero Ferrifero and the Meridional Espinhaço in the DCA and UPGMA analyses is of great interest, since it emphasises the fact that these areas of the Atlantic Forest form a continuum of semideciduous montane forests.

In contrast to some previous studies (Van den Berg \& Oliveira-Filho, 2000; Gonzaga et al., 2008), in our analysis geographical proximity exerted less influence on floristic similarity between areas. Some areas which showed floristic similarity were geographically far apart; these included some in different water basins, such as Aimorés and Governador Valadares in the Rio Doce basin and Machacalis in the Rio Itanhém basin. However, in many cases, geographical proximity does involve similarity in several environmental variables which results in a similar flora, as is shown by the grouping of areas in the Viçosa area (Fig. 2).

Nevertheless, it should be remembered that the factors we have considered are only part of the explanation for the current floristic composition of the semideciduous forests in the Atlantic Forest. These explanations are based only on present-day aspects (i.e. climate and species distribution), and historical factors (e.g. involving the biogeography of taxa, as well as climatic fluctuation during the Pleistocene) may also have played a role.

\section{Phytogeography of the forests of the Espinhaço Range}

Forests throughout the Espinhaço Range are floristically very heterogeneous, reflecting the variety of climates, lithology, relief, soils and floristic domains found in this geological formation (Ab'Saber, 1971; Giulietti \& Pirani, 1988; Saadi, 1995; Almeida-Abreu \& Renger, 2002; Silva, 2005). The floristic affinities of each forest area are not obvious because the forest structure and composition varies, even over small areas (Harley, 1995). In fact, over all the analyses, floristic dissimilarity was the rule, often strikingly so, in adjacent localities (Fig. 1B; Tables 1,2).

The sites clustered in group 1 of the UPGMA analysis (Fig. 2), largely confirmed with the correspondence analysis (Fig. 3) and partially so with the Jaccard index (Table 2), correspond to the 'Espinhaço Central' of Kamino et al. (2008). The UPGMA group 1 includes forest areas situated throughout the Espinhaço Range (Meridional and Septentrional Espinhaço and the Chapada Diamantina) independent of geographic proximity; for example, the high level of similarity in areas as far apart as Diamantina and Catolés $(35.0 \%$ ) is outstanding (Table 2). These are the typical forest communities of the Espinhaço Range, being found within the campos rupestre, 
the most typical vegetation of Espinhaço. The floristic and physiognomic affinity of these forests is analogous to the gallery forests and pockets of semideciduous forest in the Cerrado domain, i.e. they are restricted to areas with richer and deeper soil and show floristic affinity with similar forest domains, despite being isolated within herbaceous or savanna vegetation.

In spite of the difficulty in clearly discerning factors responsible for floristic similarity between each area, particularly as floristic lists were often the result of surveys in which phytophysiognomies were not clearly distinguished, it seems likely that the campo rupestre possesses a combination of habitat features that lead to the development of a distinct forest type. These are defined by the following:

- Factors linked to high altitude, such as an increase in humidity and a decrease in air temperature (Grubb, 1977). These factors can both limit and stimulate the establishment of certain species. Among those with more than $50 \%$ occurrence in the 'Espinhaço Central' group are the following typical upland species: Hedyosmum brasiliense Miq. (Chloranthaceae), Clethra scabra Pers. (Clethraceae), Erythroxylum vaccinifolium Mart. (Erythroxylaceae), Miconia chartacea Triana (Melastomataceae), Macropeplus ligustrinus (Tul.) Perkins (Monimiaceae) and Drimys brasiliensis Miers (Winteraceae) (see data for distributions in Giulietti \& Pirani, 1988; Oliveira-Filho \& Fontes, 2000; Santos \& Peixoto, 2001) (Table 3).

- Factors linked to the soil, which in the case of campo rupestre is shallow and nutrient-poor (Silva, 2005), which limits the establishment of certain species. Furthermore, soil factors which limit forest expansion facilitate the penetration of light, thereby favouring the establishment of heliophytes to the detriment of shade-tolerant species (at least in some phenological stages). Thus, Tapirira obtusa (Benth.) J.D.Mitch. (Anacardiaceae), Alchornea triplinervia (Spreng.) Müll.Arg. (Euphorbiaceae), Pera glabrata (Schott) Poepp. ex Baill. (Euphorbiaceae), Cabralea canjerana (Vell.) Mart. (Meliaceae), Myrcia splendens (Sw.) DC. (Myrtaceae), Myrcia tomentosa (Aubl.) DC. (Myrtaceae) and Zanthoxylum rhoifolium Lam. (Rutaceae) are very common heliophyte species in these areas (Table 3).

Several authors have stated that the restricted and endemic distribution pattern in the campo rupestre applies mainly to herbaceous and shrub species, whereas many of the arboreal species are widely distributed throughout Brazilian forest domains (Giulietti et al., 1987; Giulietti \& Pirani, 1988; Meguro et al., 1996). The 'Espinhaço Central' group recognised in our analysis does indeed contain some species with a wide distribution. Examples of such taxa (with more than 50\% occurrence) are: Tapirira guianensis Aubl. (Anacardiaceae), Alchornea triplinervia, Emmotum nitens (Benth.) Miers (Icacinaceae), Copaifera langsdorffii Desf. (Leguminosae), Andira fraxinifolia Benth. (Leguminosae), Bowdichia virgilioides Kunth (Leguminosae), Myrsine umbellata Mart. (Myrsinaceae), Guapira opposita (Vell.) Reitz (Nyctaginaceae), Roupala montana Aubl. (Proteaceae), Zanthoxylum rhoifolium and Vochysia tucanorum Mart. (Vochysiaceae). 
With regard to arboreal species that are endemic to the Espinhaço Range, there are few records in the literature, and most are also distributed in the Quadrilátero Ferrífero. Among these are (by family):

- Annonaceae: Guatteria notabilis Mello-Silva \& Pirani, endemic to forests of the Espinhaço Range, and Guatteria rupestris Mello-Silva \& Pirani, endemic to forests of the Meridional and Septentrional parts of the Espinhaço Range (Mello-Silva \& Pirani, 2003);

- Apocynaceae: Aspidosperma dispermum Müll.Arg., endemic to forest areas of the Meridional and Septentrional Espinhaço Range (Oliveira \& Pirani, 2003);

- Asteraceae: Gochnatia hatschbachii Cabrera, endemic to the Serra do Cipó (Meridional Espinhaço Range), which, although it does occur in forests, is more common in open areas (Roque \& Pirani, 1997);

- Ebenaceae: Diospyros ketun B.Walln., cited for forests of the Meridional and Septentrional Espinhaço Range and the Quadrilátero Ferrífero (Wallnöfer, 1999; Santos \& Sano, 2004);

- Lauraceae: Nectandra venulosa Meisn. (Lauraceae), endemic to forests of the Meridional Espinhaço Range (Rohwer, 1993; Oliveira-Filho, 2006); Ocotea calliscypha L.C.S.Assis \& Mello-Silva, cited for forests of the Meridional Espinhaço Range and the Quadrilátero Ferrífero (Assis \& Mello-Silva, 2009); Ocotea oppositifolia S.Yasuda, endemic to forests of the Espinhaço Range (Yasuda, 1996; Assis et al., 2004);

- Malvaceae: Pseudobombax riopretense Ravenna, endemic to forest areas of the Meridional and Septentrional Espinhaço Range (Ravenna, 2005; Oliveira-Filho, 2006);

- Myrtaceae: Eugenia laruotteana Cambess., endemic to forests of the Meridional and Septentrional Espinhaço Range (Kawasaki, 2004); Myrciaria glanduliflora (Kiaersk.) Mattos \& D.Legrand, endemic to forest areas and open country in the Meridional and Septentrional Espinhaço Range (Kawasaki, 1989, 2004; Sobral, 1993); Plinia espinhacensis Sobral, endemic to forests of the Meridional Espinhaço Range (Sobral, 2010);

- Proteaceae: Euplassa semicostata Plana, found in the cerrado and gallery forest in the Meridional Espinhaço Range and Quadrilátero Ferrífero (Plana \& Prance, 2004).

Because they are rare, these species do not account for the floristic similarities between areas of the Espinhaço; the similarities are usually due to more common taxa. However, these endemic forest species perhaps reflect a complex vegetational history of expansions and regressions of semideciduous woodlands in the Pleistocene (Ledru et al., 1996, 2009; Behling, 2002).

In addition to their 'Espinhaço Central' group, Kamino et al. (2008) recognised other communities that are also reflected in the groups found in our analyses, although in all cases such groups are better understood within the context of a wider survey of the Atlantic Forest. For example, the similarity between Chapada de São Domingos and Leme do Prado (the sites that constitute the 'Chapada de São Domingos' group sensu 
Kamino et al., 2008) with two other areas (Posse and Virgem da Lapa), all of them in the Jequitinhonha basin, indicates that this group is more closely related to the vegetation in this river basin than to that of the Espinhaço forests.

The 'Quadrilátero Ferrífero' group (sensu Kamino et al., 2008) appears as a relatively robust group in our UPGMA analysis (group 3.2), although several localities included by Kamino et al. (2008) (e.g. Belo Horizonte and Ouro Preto) were excluded from our grouping, as also was Santa Bárbara, which was grouped with areas in the Rio Doce and Rio Paraíba do Sul basins. Floristic affinity within the Quadrilátero Ferrífero group may be correlated with the upland character of its forests and geographical proximity. Although not clustered with group 3.2, Santa Bárbara showed high similarity (Jaccard index $>25 \%$ ) with the Mariana and Nova Lima sites, thus providing some support for the floristic affinity among Quadrilátero Ferrífero areas. The sites at Belo Horizonte and Ouro Preto are very degraded areas and this could explain their low affinity with the others in the Quadrilátero Ferrífero. No species with restricted distributions occur in group 3.2, since the similarity was due to shared species with relatively wide distributions, such as Copaifera langsdorffi, Myrsine umbellata, Guapira opposita and Zanthoxylum rhoifolium. In both analyses (cluster and correspondence), this group also showed an affinity with areas in the Alto Rio Grande, although it is difficult to identify any particular factor influencing this pattern.

Finally, it is important to emphasise, as have other authors (Harley, 1995; Kamino et al., 2008), the need for further studies on forests throughout the Espinhaço Range, in particular because of the heterogeneity and large area of this formation. Moreover, a greater understanding of the regional geomorphology is necessary since much floristic variation is linked to this factor (Harley, 1995). Palaeontological studies that may shed light on the history of the forest vegetation of the area are also required.

\section{CONCLUSION}

- The prevailing relief in the basins of the Alto Rio Grande, Rio Jequitinhonha, Rio Doce, Rio Itanhém and Rio Paraíba do Sul has exerted an influence on rainfall and seasonality in these areas which, in turn, has exerted a major influence on the composition of their semideciduous forests.

- Geographic proximity and altitude, although important factors, played a secondary role in the phytogeographic patterns analysed.

- In spite of the pronounced floristic heterogeneity encountered throughout the forests of the Espinhaço Range, there is a physiognomic and floristic affinity among some areas, namely those within the campo rupestre vegetation.

\section{ACKNOWLEDGEMENTS}

We thank the following: CAPES for grants to the first two authors, and CNPq for a grant to the third author; Prof. Ary T. de Oliveira-Filho and Prof. José R. Pirani 
for their suggestions on an earlier version of this paper; the Editor and the anonymous reviewers for the many valuable comments; and Talita C. O. Ferreira and Leonardo M. Borges for their help with the map.

\section{REFERENCES}

А в'S A BeR, A. N. (1971). A organização natural das paisagens Inter e Subtropicais do Brasil. In: III Simpósio Sobre o Cerrado. São Paulo: Edusp.

Almeida-Abreu, P. A. (1995). O Supergrupo Espinhaço da Serra do Espinhaço Meridional (Minas Gerais): o rifte, a bacia e o orógeno. Geonomos 3: 1-18.

Almeida-Abreu, P. A. \& Renger, F. E. (2002). Serra do Espinhaço meridional: um orógeno de colisão do mesoproterozóico. Revista Brasil. Geocien. 32(1): 1-14.

Almeida-Abreu, P. A., Fraga, L. M. S. \& Neves, S. C. (2005). Geologia. In: Silva, A. C., Pedreira, L. C. V. S. \& Almeida-Abreu, P. A. (eds) Serra do Espinhaço Meridional: paisagens e ambientes, pp. 19-43. Belo Horizonte: O Lutador.

Assis, L. C. S. \& Mello-Silva, R. (2009). Three new species of Ocotea (Lauraceae) from the Brazilian Atlantic Forest. Rodriguesia 60(3): 641-649.

Assis, L. C. S., Mello-Silva, R. \& Van der Werff, H. V. D. (2004). Flora de Grão-Mogol, Minas Gerais: Lauraceae. Bol. Bot. Univ. São Paulo 22(2): 205-211.

Baitello, J. B., Hernandez, F. L., Moraes, P. L. R., Esteves, R. \& Marcovino, J. R. (2003). Lauraceae. In: Wanderley, M. G. L., Shepherd, G. J., Giulietti, A. M. \& Melhem, T. S. (eds) Flora Fanerogâmica do Estado de São Paulo, vol. 3, pp. 149-224. São Paulo: FAPESP, RiMa.

Behling, H. (2002). South and southeast Brazilian grasslands during Late Quaternary times: a synthesis. Palaeogeography, Palaeoclimatology, Palaeoecology 177: 19-27.

Berg, C. C. (1972). Olmedieae-Brosimeae (Moraceae). Fl. Neotrop. Monogr. 7: 1-228.

Botrel, R. T., Oliveira-Filho, A. T., Rodrigues, L. A. \& Curi, N. (2002). Influência do solo e topografia sobre as variações da composição florística e estrutura da comunidade arbóreo-arbustiva de uma floresta estacional semidecidual em Ingaí. Revista Brasil. Bot. 25: 195-213.

Campos, G. (1926). Mappa florestal do Brasil. Ministério da Agricultura, indústria e comércio (Serviço de Informações). Rio de Janeiro: Typ. do Serviço de Informações.

Campos, M. T. V. A. (1995). Composição florística e aspectos da estrutura e da dinâmica de três capões na Serra do Cipó, Minas Gerais, Brasil. Masters dissertation, Universidade de São Paulo, São Paulo.

Carvalho, A. M. (1997). A synopsis of the genus Dalbergia (Fabaceae: Dalbergieae) in Brazil. Brittonia 49(1): 87-109.

Carvalho, D. A., Oliveira-Filho, A. T., Vilela, E. A. \& Gavilanes, M. L. (1995). Flora arbustivo-arbórea de uma mata ciliar do Alto Rio Grande em Bom Sucesso MG. Acta Bot. Brasil. 9(2): 231-245.

Carvalho, D. A., Oliveira-Filho, A. T., Vilela, E. A. \& Curi, N. (2000). Florística e estrutura da vegetação arbórea de um fragmento de floresta semidecidual às margens do reservatório da Usina Hidrelétrica Dona Rita (Itambé do Mato Dentro, MG). Acta Bot. Brasil. 14: 37-55.

Carvalho, D. A., Oliveira-Filho, A. T., Van den Berg, E., Fontes, M. A. L., Vilela, E. A., Marques, J. J. S. G. S. M. \& Carvalho, W. A. C. (2005). Variações florísticas e estruturais do componente arbóreo de uma floresta ombrófila altomontana às margens do Rio Grande, Bocaina de Minas, MG, Brasil. Acta Bot. Brasil. 19(1): 91-109. 
Carvalho, W. A. C., Oliveira-Filho, A. T., Fontes, M. A. L. \& Curi, N. (2007). Variação espacial da estrutura da comunidade arbórea de um fragmento de floresta semidecídua em Piedade do Rio Grande, MG, Brasil. Revista Brasil. Bot. 30(2): 315-335.

Dalanesi, P. E., Oliveira-Filho, A. T. \& Fontes, M. A. L. (2004). Flora e estrutura do componente arbóreo da floresta do Parque Ecológico Quedas do Rio Bonito, Lavras MG, e correlações entre a distribuição das espécies e variáveis ambientais. Acta Bot. Brasil. 18: 737-757.

D Aly, D. C. (2002). Crepidospermum atlanticum sp. nov., a genus new to the Atlantic Forest complex of eastern Brazil. Studies in Neotropical Burseraceae X. Kew Bull. 57(2): 471-477.

Duarte, M. C., Esteves, G. L. \& Semir, J. (2007). Bombacaceae. In: Wanderley, M. G. L., Shepherd, G. J., Giulietti, A. M. \& Melhem, T. S. (eds) Flora Fanerogâmica do Estado de São Paulo, vol. 3, pp. 21-38. São Paulo: FAPESP, RiMa.

Durigan, G., Bernacci, L. C., Franco, G. A. D. C., Arbocz, G. F., Metzger, J. P. \& Catharino, E. L. M. (2008). Estádio sucessional e fatores geográficos como determinantes da similaridade florística entre comunidades florestais no Planalto Atlântico, estado de São Paulo, Brasil. Acta Bot. Brasil. 22(1): 51-62.

Fernandes, A. \& Bezerra, P. (1990). Estudo fitogeográfico do Brasil. Fortaleza: Ed. Stylus Comunicações.

Ferreira-Júnior, W. G., Silva, A. F., Meira-Neto, J. A. A., Schaefer, C. E. G. R., Dias, A. S., Ignácio, M. \& Medeiros, M. C. M. P. M. (2007). Composição florística da vegetação arbórea de um trecho de floresta estacional semidecídua em Viçosa, Minas Gerais, e espécies de maior ocorrência na região. Revista Arv. 31(6): 1121-1130.

Gauch, H. G. (1982). Multivariate Analysis in Community Ecology. New York: Cambridge University Press.

Gavilanes, M. L., Oliveira-Filho, A. T., Carvalho, D. A. \& Vilela, E. A. (1992). Flora arbustivo-arbórea de uma mata ciliar do Alto Rio Grande em Madre de Deus de Minas - MG. Daphne 2(4): 15-24.

Gentry, A. H. (1992). Bignoniaceae - part II (Tribe Tecomeae). Fl. Neotrop. Monogr. 25(2): $1-370$.

Gillet, J. B. (1980). Commiphora (Burseraceae) in South America and its relationship to Bursera. Kew Bull. 34(3): 569-588.

Giulietti, A. M. \& Pirani, J. R. (1988). Patterns of geographic distribution of some plant species from the Espinhaço Range, Minas Gerais and Bahia. In: V Anzolini, P. F. \& Heyer, W. R. (eds) Proceedings of a Workshop on Neotropical Distribution Patterns held 12-16 January 1987, pp. 39-69. Rio de Janeiro: Academia Brasileira de Ciências.

Giulietti, A. M., Menezes, N. L., Pirani, J. R., Meguro, M. \& Wanderley, M. G. L. (1987). Flora da Serra do Cipó, Minas Gerais: Caracterização e lista de espécies. Bol. Bot. Univ. São Paulo 9: 1-159.

Giulietti, A. M., Pirani, J. R. \& Harley, R. M. (1997). Espinhaço Range Region, Eastern Brazil. In: Davis, S. D., Heywood, V. H., Herrera-MacBryde, O., Villa-Lobos, J. \& Hamilton, A. C. (eds) Centres of Plant Diversity: A Guide and Strategy for their Conservation. Vol. 3. The Americas, pp. 397-404. Cambridge, UK: WWF/ IUCN.

Gontiso, B. M. (2008). Uma geografia para a Cadeia do Espinhaço. Megadiversidade 4(1-2): 7-14.

Gonzaga, A. P. D., Oliveira-Filho, A. T., Machado, E. L. M., Hargreaves, P. \& Machado, J. N. M. (2008). Diagnóstico florístico-estrutural do componente arbóreo da floresta da Serra de São José, Tiradentes, MG, Brasil. Acta Bot. Brasil. 22(2): 505-520.

GrubB, P. J. (1977). Control of forest growth and distribution on wet tropical mountains: with special reference to mineral nutrition. Annu. Rev. Ecol. Syst. 8: 83-107. 
Harley, R. M. (1995). Introdução. In: Stannard, B. L. (ed.) Flora of the Pico das Almas, Chapada Diamantina, Bahia, Brazil. Kew: Royal Botanic Gardens.

Henderson, A., Galeano, G. \& Bernal, R. (1995). Field Guide to the Palms of the Americas. Princeton, NJ: Princeton University Press.

Instituto Brasileiro de Geografia e Estatística (IBGE) (1993). Mapa de vegetação do Brasil. Escala 1:1000000. Rio de Janeiro: IBGE.

Ivanauskas, N. M., Monteiro, R. \& Rodrigues, R. R. (2000). Similaridade florística entre áreas de floresta atlântica no estado de São Paulo. Brazil. J. Ecol. 1\&2: 71-81.

Jesus, R. M. \& Garcia, A. (1992). Index Seminum - Reserva florestal de Linhares, Espírito Santo, Brasil. In: Anais - $2^{\circ}$ Congresso Nacional sobre Essências Nativas, pp. 306-317.

Joffily, A. \& Vieira, R. C. (2006). Lectotypification of Goniodiscus elaeospermus and new synonyms for Maytenus (Celastroideae-Celastraceae) from Brazil. Kew Bull. 61: 265-267.

Joly, C. A., Aidar, M. P. M., Klink, C. A., McGrath, D. G., Moreira, A. G., Moutinho, P. et al. (1999). Evolution of the Brazilian phytogeography classification systems: implications for biodiversity conservation. Environ. \& Biodivers. 51(5/6): 331-348.

Kamino, L. H. Y., Oliveira-Filho, A. T. \& Stehmann, J. R. (2008). Relações florísticas entre as fitofisionomias florestais da Cadeia do Espinhaço, Brasil. Megadiversidade 4(1-2): 38-77.

Kawasak , M. L. (1989). Flora da Serra do Cipó, Minas Gerais: Myrtaceae. Bol. Bot. Univ. São Paulo 11: 121-170.

Kawasak i, M. L. (2004). Flora de Grão-Mogol, Minas Gerais: Myrtaceae. Bol. Bot. Univ. São Paulo 22(2): 323-337.

Kovach, W. L. (2004). Multivariate Statistical Package. Version 3.1 for Windows.

Landrum, L. R. (1986). Campomanesia, Pimenta, Blepharocalyx, Legrandia, Acca, Myrrhinium, and Luma (Myrtaceae). Fl. Neotrop. Monogr. 45: 1-179.

Ledru, M. P., Soares Braga, P. I., Soubiès, F., Fournier, M., Martin, L., Suguio, K. \& Turcq, B. (1996). The last 50,000 years in the Neotropics (Southern Brazil): evolution of vegetation and climate. Palaeogeography, Palaeoclimatology, Palaeoecology 123: 239-257.

Ledru, M., Mourguiart, P. \& Riccomini, C. (2009). Related changes in biodiversity, insolation and climate in the Atlantic rainforest since the last interglacial. Palaeogeography, Palaeoclimatology, Palaeoecology 271: 140-152.

Leitão-Filho, H. F. (1987). Considerações sobre a florística de florestas tropicais e subtropicais do Brasil. IPEF 35: 41-46.

Lima, R. B. (2000). A familia Rhamnaceae no Brasil: diversidade e taxonomia. $\mathrm{PhD}$ thesis, Universidade de São Paulo, São Paulo.

Lombardi, J. A. \& Gonçalves, M. (2000). Composição florística de dois remanescentes de Mata Atlântica do sudeste de Minas Gerais, Brasil. Revista Brasil. Bot. 23(3): 255-282.

Lopes, R. M. F., França, G. S., Silva, F. R. G., Sposito, T. C. S. \& Stehmann, J. R. (2009). Estrutura do componente arbóreo de floresta estacional semidecidual montana secundária no Alto Rio Doce, Minas Gerais, Brasil. Rodriguesia 60(4): 1037-1053.

Lopes, W. P., Paula, A., Sevilha, A. C. \& Silva, A. F. (2002). Composição da flora arbórea de um trecho de floresta estacional no jardim botânico da Universidade Federal de Viçosa (face sudoeste), Viçosa, Minas Gerais. Revista Arv. 26(3): 339-347.

Maas, P. J. M., Kamer, H. M., Junikka, L., Mello-Silva, R. \& Rainer, H. (2001). Annonaceae from central-eastern Brazil. Rodriguesia 52(80): 65-98.

Marangon, L. C., Soares, J. J. \& Feliciano, A. L. P. (2003). Florística arbórea da Mata da Pedreira, município de Viçosa, Minas Gerais. Revista Arv. 27(2): 207-215. 
Meguro, M., Pirani, J. R., Mello-Silva, R. \& Giulietti, A. M. (1996). Caracterização florística e estrutural de matas ripárias e capões de altitude na Serra do Cipó, Minas Gerais. Bol. Bot. Univ. São Paulo 15: 13-29.

Meira-Neto, J. A. A. \& Martins, F. R. (2002). Composição florística de uma floresta estacional semidecidual Montana no município de Viçosa - MG. Revista Arv. 26(4): 437-446.

Mello-Silva, R. \& Pirani, J. R. (2003). Flora de Grão-Mogol, Minas Gerais: Annonaceae. Bol. Bot. Univ. São Paulo 21(1): 67-72.

Mendonça, J. O. \& Amaral Júnior, A. (2002). Erythroxylaceae. In: Wanderley, M. G. L., Shepherd, G. J., Giulietti, A. M. \& Melhem, T. S. (eds) Flora Fanerogâmica do Estado de São Paulo, vol. 3, pp. 107-120. São Paulo: FAPESP, RiMa.

Meyer, S. T., Silva, A. F., Marco-Júnior, P. \& Meira-Neto, J. A. (2004). Composição florística da vegetação arbórea de um trecho de floresta de galeria do Parque Estadual do Rola-Moça na região metropolitana de Belo Horizonte, MG, Brasil. Acta Bot. Brasil. 18(4): 701-709.

Mitchell, J. D. \& Daly, D. C. (1993). A revision of Thyrsodium (Anacardiaceae). Brittonia 45(2): 115-129.

Mueller-Dombois, D. \& Ellenberg, H. (1974). Aims and Methods of Vegetation Ecology. New York: Wiley \& Sons.

Oliveira, A. A. \& Pirani, J. R. (2003). Flora de Grão-Mogol, Minas Gerais: Apocynaceae s.1. exceto Asclepiadoideae. Bol. Bot. Univ. São Paulo 21(1): 73-82.

Oliveira-Filho, A. T. (2006). Catálogo das árvores nativas de Minas Gerais: mapeamento e inventário da flora nativa e dos reflorestamentos de Minas Gerais. Lavras: Ed. UFLA.

Oliveira-Filho, A. T. (2010). TreeAtlan 2.0, Flora arbórea da América do Sul cisandina tropical e subtropical: Um banco de dados envolvendo biogeografia, diversidade e conservação. Universidade Federal de Minas Gerais (www.icb.ufmg.br/treeatlan/).

Oliveira-Filho, A. T. \& Fontes, M. A. L. (2000). Patterns of floristic differentiation among Atlantic forests in Southeastern Brazil and the influence of climate. Biotropica 32(4b): 793-810.

Oliveira-Filho, A. T. \& Machado, J. N. M. (1993). Composição florística de uma floresta semidecídua Montana, na Serra de São José, Tiradentes, Minas Gerais. Acta Bot. Brasil. 7(2): 71-88.

Oliveira-Filho, A. T., Vilela, E. A., Gavilanes, M. L. \& Carvalho, D. A. (1994). Comparison of the woody flora and soils of six montane semi-deciduous forests in southern Minas Gerais, Brazil. Edinburgh J. Bot. 51: 355-389.

Oliveira-Filho, A. T., Carvalho, D. A., Fontes, M. A. L., Van den Berg, E., Curi, N. \& Carvalho, W. A. C. (2004a). Variações estruturais do compartimento arbóreo de uma floresta semidecídua alto-montana na chapada dos perdizes, Carrancas, MG. Revista Brasil. Bot. 27(2): 291-309.

Oliveira-Filho, A. T., Carvalho, D. A., Vilela, E. A., Curi, N. \& Fontes, M. A. L. (2004b). Diversity and structure of the tree community of a fragment of tropical secondary forest of the Brazilian Atlantic Forest domain 15 and 40 years after logging. Revista Brasil. Bot. 27(4): 685-701.

Oliveira-Filho, A. T., Tameirão-Neto, E., Carvalho, W. A. C., Werneck, M., Brina, A. E., Vidal, C. et al. (2005). Análise florística do compartimento arbóreo de áreas de floresta atlântica sensu lato na região das bacias do leste (Bahia, Minas Gerais, Espírito Santo e Rio de Janeiro). Rodriguesia 56(87): 185-235.

Oliveira-Filho, A. T., Jarenkow, J. A. \& Rodal, M. J. N. (2006). Floristic relationships of seasonally dry forests of eastern South America based on tree species distribution patterns. In: Pennington, R. T., Ratter, J. A. \& Lewis, G. P. (eds) 
Neotropical Savannas and Dry Forests: Plant Diversity, Biogeography and Conservation. Boca Raton, FL: CRC Press.

Pedralli, G. \& Teixeira, M. C. B. (1997). Levantamento florístico e principais fisionomias da Estação de Pesquisa e Desenvolvimento Ambiental de Peti, Santa Bárbara, estado de Minas Gerais, Brasil. Iheringia, Série Biológica 48: 15-40.

Pedralli, G., Freitas, V. L. O., Meyer, S. T., Teixeira, M. C. B. \& Gonçalves, A. P. S. (1997). Levantamento florístico na Estação Ecológica do Tripuí, Ouro Preto, Minas Gerais. Acta Bot. Brasil. 11: 191-213.

Pedreira, A. J. (1994). O Supergrupo Espinhaço na Chapada Diamantina Centro-oriental, Bahia: sedimentologia, estratigrafia e tectônica. $\mathrm{PhD}$ thesis, Universidade de São Paulo, São Paulo.

Pennington, T. D. (1990). Sapotaceae. Fl. Neotrop. Monogr. 52: 1-770.

Pereira, I. M., Oliveira-Filho, A. T., Botelho, S. A., Carvalho, W. A. C., Fontes, M. A. L., Schiavini, I. \& Silva, A. F. (2006). Composição florística do compartimento arbóreo de cinco remanescentes florestais do maciço do Itatiaia, Minas Gerais e Rio de Janeiro. Rodriguesia 57(1): 103-126.

Pielou, E. C. (1984). The Interpretation of Ecological Data. Wiley-Interscience.

Pifano, D. S., Valente, A. S. M., Castro, R. M., Pivari, M. O. D., Salimena, F. R. G. \& Oliveira-Filho, A. T. (2007). Similaridade entre os habitats da vegetação do Morro do Imperador, Juiz de Fora, Minas Gerais, com base na composição de sua flora fanerogâmica. Rodriguesia 58(4): 885-904.

Pirani, J. R., Giulietti, A. M., Mello-Silva, R. \& Meguro, M. (1994). Checklist and patterns of geographic distribution of the vegetation of Serra do Ambrósio, Minas Gerais, Brazil. Revista Brasil. Bot. 17(2): 133-147.

Pirani, J. R., Mello-Silva, R. \& Giulietti, A. M. (orgs.) (2003). Flora de GrãoMogol, Minas Gerais, Parte I, Pteridófitas, Podocarpaceae, Angiospermas A-D. Bol. Bot. Univ. São Paulo 21(1): 1-249.

Pirani, J. R., Mello-Silva, R. \& Giulietti, A. M. (orgs.) (2004). Flora de Grão-Mogol, Minas Gerais, Parte II, Angiospermas E-O. Bol. Bot. Univ. São Paulo 22(2): $1-387$.

Pirani, J. R., Mello-Silva, R. \& Giulietti, A. M. (orgs.) (2006). Flora de Grão-Mogol, Minas Gerais, Parte III, Angiospermas P-T. Bol. Bot. Univ. São Paulo 24: $1-129$.

Plana, V. \& Prance, G. T. (2004). A synopsis of the South American genus Euplassa (Proteaceae). Kew Bull. 59(1): 27-45.

Prance, G. T. (1989). Chrysobalanaceae, supplement. Fl. Neotrop. Monogr. 9: 1-267.

Queiroz, L. P. (2009). Leguminosas da Caatinga. Feira de Santana: Universidade Estadual de Feira de Santana.

Ratter, J. A., Bridgewater, S. \& Ribeiro, J. F. (2003). Analysis of the floristic composition of the Brazilian cerrado vegetation III: Comparison of the woody vegetation of 376 areas. Edinburgh J. Bot. 60: 57-109.

Ravenna, P. (2005). New species of South American Pseudobombax, noteworthy Ceiba species and a new section with $C$. jasminodora as type (Bombacaceae). Onira Bot. Leafl. 10(10): 29-30.

Rizzini, C. T. (1979). Tratado de fitogeografia do Brasil: aspectos ecológicos, sociológicos e floristicos. Rio de Janeiro: Âmbito Cultural Edições LTDA.

Rocha, C. T. V., Carvalho, D. A., Fontes, M. A. L., Oliveira-Filho, A. T., Van den Berg, E. \& Marques, J. J. G. S. M. (2005). Comunidade arbórea de um continuum entre floresta paludosa e de encosta em Coqueiral, Minas Gerais, Brasil. Revista Brasil. Bot. 28(2): 203-218. 
Rodrigues, L. A., Carvalho, D. A., Oliveira-Filho, A. T., Botrel, R. T. \& Silva, E. A. (2003). Florística e estrutura da comunidade arbórea de um fragmento florestal em Luminárias, MG. Acta Bot. Brasil. 17: 71-87.

Rohwer, J. G. (1988). The genera Dicypellium, Phyllostemonodaphne, Systemonodaphne, and Urbanodendron (Lauraceae). Bot. Jahrb. Syst. 110: 157-171.

Rohwer, J. G. (1993). Lauraceae (Nectandra). Fl. Neotrop. Monogr. 60: 1-332.

Rolim, S. G., Ivanauskas, N. M., Rodrigues, R. R., Nascimento, M. T., Gomes, J. M. L., Folli, D. A. \& Couto, H. T. Z. (2006). Composição florística do estrato arbóreo da Floresta Estacional Semidecidual na Planície Aluvial do rio Doce, Linhares, ES, Brasil. Acta Bot. Brasil. 20(3): 549-561.

Roque, N. \& Pirani, J. R. (1997). Flora da Serra do Cipó, Minas Gerais: Compositae Barnadesieae e Mutisieae. Bol. Bot. Univ. São Paulo 16: 151-185.

Rosière, C. A. \& Chemale, F., Jr. (2000). Brazilian iron formations and their geological setting. Revista Brasil. Geocien. 30(2): 274-278.

SAADi, A. (1995). A geomorfologia da Serra do Espinhaço em Minas Gerais e de suas margens. Geonomos 3(1): 41-63.

Salis, S. M., Shepherd, G. J. \& Joly, C. A. (1995). Floristic comparison of mesophytic semideciduous forests of the interior of the state of São Paulo, Southeast Brazil. Vegetatio 119: $155-164$.

Santos, A. M. M., Silva, J. M. C. \& Tabarelli, M. (2007). Biogeographical relationships among tropical forests in northeastern Brazil. J. Biogeogr. 34: 437-446.

Santos, I. S. \& Peixoto, A. L. (2001). Taxonomia do gênero Macropeplus Perkins (Monimiaceae, Monimioideae). Rodriguesia 52(81): 65-105.

S Antos, L. B. (1943). Aspecto geral da vegetação do Brasil. Boletim Geográfico, Rio de Janeiro 1: 68-73.

S antos, M. F. (2009). Análise floristica em floresta estacional semidecidual na encosta leste da Serra do Cipó, MG. Masters dissertation, Universidade de São Paulo, São Paulo.

Santos, M. F. \& Sano, P. T. (2004). Flora de Grão Mogol, Minas Gerais: Ebenaceae. Bol. Bot. Univ. São Paulo 22(2): 93-95.

Scalon, V. R. (2007). Revisão taxonômica do gênero Stryphnodendron Mart. (Leguminosae-Mimosoideae). PhD thesis, Universidade de São Paulo, São Paulo.

Scudeller, V. V., Martins, F. R. \& Shepherd, G. J. (2001). Distribution and abundance of arboreal species in the Atlantic ombrophilous dense forest in Southeastern Brazil. Pl. Ecol. 152: 185-199.

Silva, A. C. (2005). Solos. In: Silva, A. C., Pedreira, L. C. V. S. \& AlmeidaA в reu, P. A. (eds) Serra do Espinhaço Meridional: paisagens e ambientes, pp. 59-78. Belo Horizonte: O Lutador.

Silva, C. T., Reis, G. G., Reis, M. G. F., Silva, E. \& Chaves, R. A. (2004). Avaliação temporal da florística arbórea de uma floresta secundária no município de Viçosa, Minas Gerais. Revista Arv. 28(3): 429-441.

Silva, G. C. \& Nascimento, M. T. (2001). Fitossociologia de um remanescente de mata sobre tabuleiros no norte do estado do Rio de Janeiro (Mata do Carvão). Revista Brasil. Bot. 24(1): 51-62.

Skorupa, L. A. (1996). Revisão taxonômica de Pilocarpus Vahl (Rutaceae). PhD thesis, Universidade de São Paulo, São Paulo.

Sleumer, H. (1980). Flacourtiaceae. Fl. Neotrop. Monogr. 22: 1-499.

Sleumer, H. (1984). Olacaceae. Fl. Neotrop. Monogr. 38: 1-159.

Soares, M. P., Saporetti-Junior, A. W., Meira-Neto, J. A. A., Silva, A. F. \& SouzA, A. L. (2006). Composição florística do estrato arbóreo de floresta atlântica interiorana em Araponga - Minas Gerais. Revista Arv. 30(5): 859-870. 
Sobral, M. (1993). Sinopse de Myrciaria (Myrtaceae). Napaea 9: 13-41.

Sobral, M. (2010). Ten new Myrtaceae from eastern and northeastern Brazil. J. Bot. Res. Inst. Texas 4(1): 133-158.

SOS Mata Atlântica \& INPE (1993). Evolução dos remanescentes florestais e ecossistemas associados do domínio da Mata Atlântica. Fundação SOS Mata Atlântica, São Paulo: Instituto Nacional de Pesquisas Espaciais.

Ter Braak, C. J. F. (1995). Ordination. In: Jongman, R. H. G., Ter Braak, C. J. F. \& van Tongeren, O. F. R. (eds) Data Analysis in Community and Landscape Ecology. Cambridge, UK: Cambridge University Press.

Torres, R. B., Martins, F. R. \& Kinoshita, L. S. (1997). Climate, soil and tree flora relationships in forests in the state of São Paulo, southeastern Brasil. Revista Brasil. Bot. 20(1): 41-49.

Van den Berg, E. \& Oliveira-Filho, A. T. (2000). Composição florística e estrutura fitossociológica de uma floresta ripária em Itutinga, Minas Gerais, e comparação com outras áreas. Revista Brasil. Bot. 23(3): 231-253.

Veloso, H. P., Rangel Filho, A. L. R. \& Lima, J. C. A. (1991). Classificação da vegetação brasileira adaptada a um sistema universal. Rio de Janeiro - RJ: FIBGE.

Wallnöfer, B. (1999). Neue Diospyros-Arten (Ebenaceae) aus Südamerika. Ann. Naturhist. Mus. Wien 101B: 565-592.

Werneck, M. S., Pedralli, G., Koenig, R. \& Giseke, L. F. (2000). Florística e estrutura de três trechos de uma floresta semidecídua na Estação Ecológica do Tripuí, Ouro Preto, MG. Revista Brasil. Bot. 23(1): 97-106.

Yasuda, S. (1996). A new species of Ocotea (Lauraceae) from the Serra do Espinhaço, Brazil. Novon 6(4): 484-486.

ZAPPi, D. (2003). Revision of Rudgea (Rubiaceae) in southeastern and southern Brazil. Kew Bull. 58: 513-596.

Zappi, D. C., Semir, J. \& Pierozzi, N. I. (1995). Genipa infundibuliformes sp. nov. and notes on Genipa americana (Rubiaceae). Kew Bull. 50(4): 761-771. 